\title{
ANALYSIS OF WELDS ON HELIUM-CONTAINING RESTRAINT TEST PLATES (U)
}

By

W. R. Kanne, Jr.

G. T. Chandler

SEPTEMBER, 1994

A report written in support of the International Thermonuclear Experimental Reactor (ITER) program. Aiken, SC 29808 


\section{DISCLAIMER}

This report was prepared as an account of work sponsored by an agency of the United States Government. Neither the United States Government nor any agency thereof, nor any of their employees, makes any warranty, express or implied, or assumes any legal liability or responsibility for the accuracy, completeness, or usefulness of any information, apparatus, product, or process disclosed, or represents that its use would not infringe privately owned rights. Reference herein to any specific commercial product, process, or service by trade name, trademark, manufacturer, or otherwise does not necessarily constitute or imply its endorsement, recommendation, or favoring by the United States Government or any agency thereof. The views and opinions of authors expressed herein do not necessarily state or reflect those of the United States Government or any agency thereof.

This report has been reproduced directly from the best available copy.

Available to DOE and DOE contractors from the Office of Scientific and Technical Information, P.O. Box 62, Oak Ridge, TN 37831; prices available from (615) 576-8401.

Available to the public from the National Technical Information Service, U.S. Department of Commerce, 5285 Port Royal Road, Springfield, VA 22161. 


\section{DISCLAIMER}

Portions of this document may be illegible in electronic image products. Images are produced from the best available original document. 


\title{
WSRC-TR-94-0449
}

ASET

APPLIED SCIENCE \& ENGINEERING TECHNOLOGY

Keywords: Helium-Embrittlement

Weld Cracks

Weld Overlay

Retention:

Permanent

\section{ANALYSIS OF WELDS ON HELIUM-CONTAINING RESTRAINT TEST PLATES (U)}

by

\author{
W. R. Kanne, Jr. \\ G. T. Chandler \\ ISSUED: September, 1994
}

Authorized Derivative Classifier

SRTC SAVANNAH RIVER TECHNOLOGY CENTER, AIKEN, SC 29808

Westinghouse Savannah River Company

Prepared for the U.S. Department of Energy under Contract DE-AC09-89SR18035 
DOCUMENT: WSRC-TR-94-0449

TITLE: ANALYSIS OF WELDS ON HELIUM-CONTAINING RESTRAINT TEST PLATES (U)

APPROVALS

S. L. West, TECHNICAL REVIEWER MATERIALS TECHNOLOGY SECTION

D. T. Rankin, MANAGER

MATERIALS COMP. \& JOINING TECH. MATERIALS TECHNOLOGY SECTION

T. L. Capeletti, MANAGER

MATERIALS TECHNOLOGY SECTION
DATE:

DATE:

DATE: 
Distribution:

G. Nardella, DOE-OFE

C. C. Baker, UCSD

K. L. Wilson, SNL-CA

A. F. Rowcliffe, ORNL

M. L. Grossbeck, ORNL

S. R. Wright, 703-46A

R. E. Seif, 703-A/A-241

C. E. Ahlfeld, La Jolla, CA

E. R. Conaster, 773-41A

T. H. Gould, 773-41A

J. G. Angelos, 773-41A

B. J. Cross, 773-41A

J. R. Knight, 773-A

T. Motyka, 773-A

J. D. Cohen, 773-A

E. G. Caveness, 730-A

C. E. Sessions, 730-A

E. A. Franco-Ferreira, 730-A

T. L. Capeletti, 773-41A

M. R. Louthan, 773-A

D. T. Rankin, 773-A

N. C. Iyer, 773-A

M. J. Morgan, 773-A

S. L. West, 773-A

M. J. Morgan, 773-A

M. H. Tosten, 773-A

MTS File,

SRL Records (4), 


\title{
ANALYSIS OF WELDS ON HELIUM-CONTAINING RESTRAINT TEST PLATES
}

\author{
W. R. Kanne, Jr. \\ G. T. Chandler
}

\section{SUMMARY}

Over the last several years, Savannah River has had the goal of developing a repair process and the technical understanding necessary to make weld repairs on stainless steel containing helium. This report documents the results of a series of test welds made with varying amounts of mechanical restraint on type 304 stainless steel containing helium from tritium decay. This change in restraint produced different states of stress on the weld area during welding. The test welds were either overlay welds or weave beads. The amount of heat affected zone cracking observed in the welds provided the primary analysis tool for evaluating the tests. Generally, higher restraint produced greater cracking of the welds. These results, along with previous Savannah River data, indicate that in a practical application of a repair method for helium-containing stainless steel, the effect of part configuration must be considered, as well as the type of weld, to reduce stresses that can cause helium embrittlement cracking.

\section{INTRODUCTION}

In 1986, Savannah River test results and analysis demonstrated that helium, present in Type 304 stainless steel from either neutron irradiation or tritium decay caused cracking in the heat-affected zone of repair welds (Ref. 1). Since that time several studies have shown that welding processes which lower the stress and thermal impact in the weld heat-affected zone can reduce the amount of cracking (Ref. 2 - 5). One such process is Gas Metal Arc (GMA) overlay welding. Savannah River developed an overlay welding process which produces a low penetration weld with low heat input (Ref. 3). This overlay process eliminated surface cracking and reduced underbead cracking in tritium charged and aged 304 stainless steel containing up to $220 \mathrm{appm}$ helium. More recently overlay welding was successfully demonstrated on irradiated 304 stainless steel containing 10 appm helium (Ref. 6).

In addition to the type of welding process, the amount of stress in the heat-affected zone of welds is also a function of the restraint around the weld area. In order to determine the effect of restraint on cracking of low penetration overlay welds, a test matrix of different restraint configurations was established. The test variables included: thick vs. thin plates; wide vs. narrow plates, and longitudinal vs. transverse welds. In addition, two helium concentrations were investigated. 
The primary method for evaluation of the results of the constraint test matrix was counting of the number and size of cracks produced in the heat-affected zones of the welds made at the different conditions of restraint. In addition, the surfaces of the plates were examined both optically at $40 \mathrm{X}$ magnification and by dye penetrant inspection. The results of the surface examination were previously documented in an internal Westinghouse report, and are summarized in the section on Surface Examination in this report.

\section{TEST MATRIX}

The test matrix simulated conditions of restraint found in practice for repair of irradiated components. The goal of the test matrix was to determine the effects of material condition, weld end effects, and restraint (thermal and mechanical) on helium embrittlement damage during welding. The matrix consisted of 24 weld overlay segments made on 10 test coupons that were charged to approximately 45 or $90 \mathrm{appm}$ helium. Helium concentration was measured for each charged plate. The crack results presented in this report were normalized for differences in helium concentrations from the nominal 45 or $90 \mathrm{appm}$.

The effects of restraint caused by welding on large reinforced plate were compared to the effects of reduced restraint on unreinforced plates. Reinforcement of plates was achieved by electron beam welding uncharged plate extenders, or tabs, to the charged plates.

Four welding configurations (Figure 1) were used on 0.25 inch thick plate at each of the two helium concentrations. Welds were made transverse across helium charged plates bounded by uncharged plates as was done for previous weld tests (Ref. $2 \& 3$ ). For one condition uncharged tabs were electron beam welded to the helium charged plate, Figure 1a. For a second condition, the uncharged tabs were not welded to the charged plate but simply placed next to the charged plate, Figure 1b.

In the third and fourth conditions on the 0.25 inch thick charged plate, welds were made longitudinally on the plates. For the third condition, tabs were electron beam welded to the charged plate, Figure 1c, and for the fourth condition tabs were not connected to the charged plate, Figure $1 \mathrm{~d}$. Results were compared with and without the electron beam welded tabs. This configuration additionally allowed observation of end effects of the welds on helium charged material.

A fifth condition of restraint was achieved by using 0.45 inch thick plate for both the charged plate and the uncharged tabs in the configuration shown in Figure 1a. The effect of increased restraint resulting from the greater thickness was determined by comparison with the thinner plates in the same configuration and helium concentrations.

Comparisons were also made with gas tungsten arc weave beads. The weave beads 
were placed on the back side of the 0.45 inch thick plates of the configuration in Figure 1a. Two different welding conditions were used for the weave beads as described below.

The amount of helium embrittlement cracking during overlay welding was measured for each of the different conditions of restraint. The first stage in the damage measurement was an examination of the surface of the welded plates using dye penetrant testing and direct visual examination at low magnification. The second stage was a detailed analysis of the crack distributions in the welded plates. The results of these inspections, and their implications for the repair of helium containing stainless steel, are presented in this report.

\section{OVERLAY WELD AND WEAVE BEAD DESCRIPTION}

GMA overlay welds were made on plates in several configurations, as described in Table I, to examine the effect of thermomechanical restraint on the welds. Overlay welds were made either across the helium bearing plates or along the length of the plates. Run-on and run-off plates were either unattached to the helium bearing plate or the three plates were welded together using the electron beam process. Eight plates were 0.25 inch thick and two were 0.45 inch thick. In addition to the GMA overlay welds made on each test plate, two gas tungsten arc (GTA) weave beads (no filler metal) were made on the back side of each 0.45 inch thick plate. Therefore a total of 24 weld segments (20 GMA overlay and 4 GTA weave beads) were made on 10 helium charged test coupons. Photographs of GMA overlay welds on two plates are shown in Figures 2 and 3, and a pair of GTA weave beads is shown in Figure 4.

GMA overlay welds were made using the parameters shown in Table II with a heat input of $18.6 \mathrm{KJ} / \mathrm{in}^{2}$. The welding procedure utilized the low-penetration process developed by E. A. Franco-Ferreira ( Ref. 3) with optimization to further reduce the heat input.

GTA weave beads were made using the parameters shown in Table III. The colder procedure had a heat input approximately equal to the GMA overlay welds. One weld made by each of the two procedures was placed on the back sides on each of the two 0.45 inch thick plates that already had GMA overlay welds on the front sides. As can be seen by the photograph in Figure 3, the lower heat input weld melted the base metal only in spots. The higher heat input procedure produced melting evenly across the one inch wide area.

\section{SURFACE EXAMINATION}

\section{Dye Penetrant Test Results}

Dye penetrant tests were performed on the welded surface of the charged plates using the solvent removable red dye method. Results showed no toe cracks of the type found in the heat-affected zone of stringer beads on previous test plates (Ref. 2 
\& 3) or Savannah River Reactor repair welds (Ref. 1). There was an absence of toe cracks around the GTA weave beads and the electron beam welds, as well as the GMA overlay welds. There were no indications of any cracks of any type associated with any of the GMA overlays (see examples in Figures $5 \& 6$ ).

The GTA weave beads did, however, show significant indications, Figure 7. Porosity in the higher heat input GTA weave beads showed up dramatically, but was only present on the middle plate that contained helium. Significant red dye indications were also present on the surface of the bead that has melting only in scattered locations. As will be seen in the next section, these indications are due to a network of surface cracks.

Porosity in the electron beam welds joining the uncharged plates to the heliumbearing center plate is also visible. Where the electron beam welds had no porosity, there were no dye penetrant indications of cracking.

\section{Visual Examination Results}

Surfaces of the welds and weld heat-affected zones were examined visually at $40 \mathrm{x}$ to 50x magnification using a stereo microscope. No toe cracks were observed, confirming the dye penetrant results.

Minute crack-like indications were seen in the heat affected zones of the welds, but they were observed on both the helium-bearing and non helium-bearing plates indicating that the helium played no part in their presence. Surfaces of the electron beam welds joining the plates to each other were also examined with similar results.

The surface of the GTA weave bead that was melted only in isolated spots was uniquely different from all other surfaces. It was interlaced with a network of cracks that were prominently visible at $40 \times$ magnification. The photographs of Figure 8 show the cracks, along with bands of discoloration caused by the passage of the welding arc, and isolated spots of melting on an otherwise as-machined surface.

\section{METALLOGRAPHIC EXAMINATION}

Metallographic examination was performed on each weld as the primary method for analyzing the amount of cracking associated with welds made at each condition. Welds were sectioned longitudinally, independent of the orientation of the weld on the plate. Welds were cut such that sections in the middle of the one inch wide weld and a quarter inch in from the weld edge were examined, as shown in Figure 9. Each section was divided in half for convenience in mounting resulting in four mounted sections for each weld. Sections were polished and then etched with $10 \%$ oxalic acid at 0.3 volts for 45 seconds.

Cracks were measured and counted by examining micrographs taken at 50x magnification. A montage of overlapping photographs was prepared for each weld section. Interpretation of the micrographs was augmented by direct microscopic 
examination of the weld sections at approximately 250x magnification. This was necessary in some cases to unequivocally differentiate cracks from etched grain boundaries. Micrographs from several of the plates are shown in Figures 10-13.

Metallographic examination shows that the heat affected zone (HAZ) cracks in the helium containing plates are intergranular in nature and are dependent upon helium concentration, weld type, and constraint. No underbead cracking was observed in the non-helium plates. Figure 10 shows the typical underbead cracking observed in the GMA overlay welds. Very little porosity was observed in the weld metal and only occasionally did cracks extend for a very short distance $(\sim 0.05 \mathrm{~mm})$ into the weld metal.

The GTA weave bead welds produced increased underbead cracking as shown in Figures 11 and 12 compared to the GMA overlays. As in the previous work (Ref. 25 ), this result continues to provide strong evidence for the use of the overlay technique for welding on helium. The GTA weave bead produced with the high heat parameters (Figure 11b) had significant porosity in the weld metal compared to the GMA welds. This confirms the results observed in the dye penetrant tests. The GTA weave bead produced with the low heat parameters (Figure 12) showed very little melting. There appeared to be less cracking produced from the low heat weave compared to the high heat weave, however, the cracks appeared more prominent (wider) which is consistent with the dye penetrant and visual observations.

Figure 13 shows the EB weld used to attach the extender tabs to the helium containing plate. As shown, significant amounts of porosity were observed in the weld metal. However, no cracking was observed in the helium plate adjacent to the weld metal.

\section{CRACK ANALYSIS}

Cracks were counted and measured independently in each mounted sample, resulting in four measurements for each weld. The number of cracks and the total length of cracks in each metallographic section are tabulated in Table IV for all welds. In addition, Table IV shows the helium concentration, the restraint conditions (tabs attached with electron beam weld or unattached; plate thickness; weld orientation), and the sectioning location (center or off-center; including weld stop or start location), for each weld section. It can be noted that there is no consistent effect of the stop and start locations on amount of cracking of the longitudinal orientation welds in Table IV. For longitudinal welds, the stop and start locations are on the helium-containing plate and can therefore be compared.

The crack length measurements and crack counts were averaged and then normalized for differences in helium concentrations from the nominal 45 or 90 appm. The averaged, normalized data, presented in table $V$, were used for all the analysis discussed in the remainder of this report.

The impact of the data in Tables IV \& V can be seen more readily when it is 
presented in the form of bar charts. Conclusions about the effect of restraint are apparent from the bar charts, as discussed in the next three sub-sections.

\section{Weld Orientation and Plate Width}

The effects of weld orientation and plate width appear to be interrelated, as shown in Figures 14 and 15. Measurements of crack lengths are dependent on the orientation of the weld and the orientation of the restraint placed on the heliumbearing plate. The same data are plotted in Figures 14 and 15, with the bars arranged to emphasize differences caused by plate width in Figure 14 and by weld orientation in Figure 15.

For welds that are transverse across the plate, the amount of cracking is greater without the tabs electron beam welded to the charged plate (Figure 14). Therefore, the plate with tabs attached for greater restraint actually reduces the cracking observed in the transverse metallographic sections. This is consistent in the plates with 45 and $90 \mathrm{appm}$ helium. Just the opposite is true for the welds made longitudinally along the helium-bearing plate. The plate with more restraint (with EB welded tabs) results in more cracking in the weld heat-affected zone.

The reason for the opposite effects of the restraint on the two weld orientations may be a combination of several effects. First, the restraint is non-linear due to the tabs being attached to only two sides of the charged plates. This causes increased stress in the direction perpendicular to the long edge of the longitudinal overlays but parallel to the long edge of the transverse welds. The stress states for the metallographic sections in the longitudinal and transverse welds produced under high restraint appear to be similar. Whereas, the stress states are quite different for the metallographic sections in the longitudinal and transverse welds under the low restraint condition as shown in Figure 15. This different stress state may account for the reversal of the cracking tendency. Alternatively, since the plane of metallographic sections is parallel to the long edge for all welds, the difference may reflect a directionality in crack propagation that is reflected in the planar metallographic sections as a difference in crack length.

\section{Plate Thickness}

The effect of plate thickness on transverse weld cracking is shown in Figure 16. The effect of high restraint resulting from a thick plate is evident at the higher helium concentration. There appears to be no difference in cracking between the thick plate (0.45 inches) compared to the thin plate ( 0.25 inches) at the lower helium concentration of $45 \mathrm{appm}$. However, there is increased cracking in the thick plate compared to the thin plate at the higher helium concentration of $90 \mathrm{appm}$.

\section{Helium Concentration and Weld Type}

Earlier work (Ref. 2-7) has shown that underbead cracking in helium charged stainless steel increases with an increase in helium concentration. The previous 
work has also shown that a low-penetration weld overlay technique minimizes the adverse effects of helium on the weldability of stainless steel. The results from the present study continue to support these conclusions. Figures 17 and 18 show the effect of helium concentration and weld type on underbead cracking. With an increase in helium concentration, cracking increases in both low and high restraint conditions (Figure 17). GTA weave beads have increased cracking compared to the GMA overlays under the high restraint condition (Figure 18).

\section{CONCLUSIONS}

The test results show that changes in restraint affect the amount of helium embrittlement damage that occurs when welding on stainless steel containing helium. Higher restraint generally resulted in increased cracking. Increasing the thickness of the plate, increasing the width of the plate, and changing the orientation of the weld increased the amount of cracking.

In practical repair conditions, the restraint would normally be high. That is, repairs are usually made to fairly massive pieces where the thickness is large and the parts are wide. It is therefore important to demonstrate any repair technique on test pieces that represent the actual repair in size and shape, as well as helium content and material. Interpretation of results from small test pieces must be restricted accordingly.

\section{ACKNOWLEDGMENTS}

Planning for the test program was done by a group headed by D. T. Rankin; M. R. Louthan, Jr., M. W. Perra (Sandia National Laboratories, CA), and G. G. Lessmann (Westinghouse Science and Technology Center). Test plates were charged and aged by S. H. Goods at Sandia. Plates were joined together using electron beam welding at the Los Alamos National Laboratory. Overlay and weave welds were made by E. A. Franco-Ferreira.

Funding for data analysis and preparation of this report was provided by the International Thermonuclear Fusion Reactor (ITER) program. Funding for the experimental part of this program was provided by Savannah River Site Reactor Programs. 


\section{REFERENCES}

1. W. R. Kanne, Jr., "Remote Reactor Repair: GTA Weld Cracking Caused by Entrapped Helium", Welding Journal, p. 33-39, August 1988.

2. W. R. Kanne, Jr., G. J. Bruck, A. Madeyski, D. A. Lohmeier, M. R. Louthan, Jr., D. T. Rankin, R. P. Shogan, G. G. Lessmann, and E. A. Franco-Ferreira, "Weld Repair of Helium Degraded Reactor Vessel Material", Proceedings of the Fifth International Symposium on Environmental Degradation of Materials in Nuclear Power Systems - Water Reactors), August 25-29, 1991 published by the American Nuclear Society, 1992, p. 390-397, 401, 402.

3. E. A. Franco-Ferreira and W. R. Kanne, Jr., "Remote Reactor Repair: Avoidance of He-Induced Cracking with GMAW", Welding Journal, p. 43-51, February, 1992.

4. H. T. Lin and B. A. Chin, "The Feasibility of Welding Irradiated Materials", J. Nucl. Mater., vol. 179-181 (1991) p. 1131-1134.

5. C. A. Wang, H. T. Lin, M. L. Grossbeck, and B. A. Chin, "Suppression of HAZ Cracking during Welding of Helium-containing Materials", J. Nucl. Mater., vol. 191-194 (1992) p. 696-700.

6. W. R. Kanne, Jr., G. T. Chandler, D. Z. Nelson, E. A. Franco-Ferreira, "Welding Irradiated Stainless Steel", submitted for publication in the Journal of Nuclear Materials, June 1994.

7. W. R. Kanne, Jr., D. A. Lohmeier, K. A. Dunn, and M. H. Tosten, "Metallographic Analysis of Helium-Embrittlement Cracking of Repair Welds in Nuclear Reactor Tanks", Materials Characterization, p. 23-34, January 1993. 
Table I

TEST PLATES SUMMARY

\begin{tabular}{|c|c|c|c|c|c|}
\hline $\begin{array}{l}\text { Matrix } \\
\text { Group }\end{array}$ & $\begin{array}{l}\text { Plate } \\
\text { No. }\end{array}$ & $\begin{array}{l}\text { Helium } \\
\text { (appm) }\end{array}$ & $\begin{array}{l}\text { Weld } \\
\text { Orientation* }\end{array}$ & $\begin{array}{l}\text { E. Beam } \\
\text { Welds }\end{array}$ & $\begin{array}{l}\text { Plate } \\
\text { Thick.(in) }\end{array}$ \\
\hline $1 a$ & 26 & 44.5 & Transverse & Yes & 0.25 \\
\hline $1 a$ & 27 & 96.9 & Transverse & Yes & 0.25 \\
\hline $1 b$ & 8 & 42.4 & Transverse & No & 0.25 \\
\hline $1 b$ & 20 & 90.2 & Transverse & No & 0.25 \\
\hline $1 c$ & 25 & 44.5 & Longitudinal & Yes & 0.25 \\
\hline 1c & 28 & 86.9 & Longitudinal & Yes & 0.25 \\
\hline $1 d$ & 7 & 42.4 & Longitudinal & No & 0.25 \\
\hline $1 d$ & 19 & 90.2 & Longitudinal & No & 0.25 \\
\hline 2 & 53 & 51.5 & Transverse & Yes & 0.45 \\
\hline 2 & 55 & 85.0 & Transverse & Yes & 0.45 \\
\hline
\end{tabular}

* Relative to the length of the helium-charged plate 
Table II

\section{WELDING PARAMETERS FOR GMA OVERLAYS}

Current, A

Voltage, V

21

Travel speed, ipm

3.5

Oscillation, ipm

80

Wire diameter, in.

Heat input, $\mathrm{KJ} / \mathrm{in}^{2}$

0.035

18.6

Table III

WELDING PARAMETERS FOR GTA WEAVE BEADS

HIGH HEAT:

Current, A

Voltage, V

Travel speed, ipm

Oscillation, ipm

Wire diameter, in.

Heat input, $\mathrm{KJ} /$ in $^{2}$
64

16.7

2.0

80

none

28.5

64

10.5

1.75

80

none

20.5 
TABLE IV CRACK ANALYSIS DATA

\begin{tabular}{|c|c|c|c|c|c|c|c|c|}
\hline $\begin{array}{l}\text { Plate \#! } \\
\text { Sect. }\end{array}$ & $\begin{array}{l}\text { Weld } \\
\text { Type }\end{array}$ & $\begin{array}{l}\text { Helium } \\
\text { Content } \\
\text { (appm) }\end{array}$ & $\begin{array}{c}\text { Tab } \\
\text { Attachment }\end{array}$ & $\begin{array}{c}\text { Plate } \\
\text { Thickness }\end{array}$ & $\begin{array}{l}\text { Section } \\
\text { Position }\end{array}$ & $\begin{array}{c}\text { Weld } \\
\text { Orientation }\end{array}$ & $\begin{array}{l}\text { \# cracks/ } \\
\text { weld length } \\
\text { (\#/in.) }\end{array}$ & $\begin{array}{l}\text { Total crack } \\
\text { length/ } \\
\text { weld length } \\
\text { (in./in.) }\end{array}$ \\
\hline $\begin{array}{l}26 / \mathrm{Aa} \\
26 / \mathrm{Ab}\end{array}$ & $\begin{array}{l}\text { GMA } \\
\text { GMA }\end{array}$ & $\begin{array}{l}44.5 \\
44.5\end{array}$ & EB Welded & 0.25 & Center/run-off & Transverse & 47.3 & $\begin{array}{l}0.33 \\
0.30\end{array}$ \\
\hline $26 / A c$ & GMA & $\begin{array}{l}44.5 \\
44.5\end{array}$ & EB Welded & $\begin{array}{l}0.20 \\
0.25\end{array}$ & Off-Ctr/run-off & $\begin{array}{l}\text { Iransverse } \\
\text { Transverse }\end{array}$ & $\begin{array}{l}49.0 \\
41.1\end{array}$ & 0.26 \\
\hline 26/Ad & GMA & 44.5 & EB Welded & 0.25 & Off-Ctr/run-on & Transverse & 48.9 & 0.32 \\
\hline $27 / \mathrm{Aa}$ & GMA & 96.9 & EB Welded & 0.25 & Center/run-off & Transverse & 61.2 & 0.65 \\
\hline $27 / A b$ & GMA & 96.9 & EB Welded & 0.25 & Center/run-on & Transverse & 51.0 & 0.45 \\
\hline $27 / \mathrm{Ac}$ & GMA & 96.9 & EB Welded & 0.25 & Off-Ctr/run-off & Transverse & 42.2 & 0.43 \\
\hline 27/Ad & GMA & 96.9 & EB Welded & 0.25 & Off-Ctr/run-on & Transverse & 50.3 & 0.50 \\
\hline B/Aa & GMA & 42.4 & No EB Weld & 0.25 & Center/run-off & Transwerse & 41.6 & 0.31 \\
\hline $8 / A b$ & GMA & 42.4 & No EB Weld & 0.25 & Center/run-on & Transverse & 32.9 & 0.29 \\
\hline $8 / A C$ & GMA & 42.4 & No EB Weld & 0.25 & Off-Ctr/run-off & Transverse & 47.9 & 0.50 \\
\hline 8/Ad & GMA & 42.4 & No EB Weld & 0.25 & Off-Ctr/run-on & Transverse & 61.3 & 0.64 \\
\hline $20 / \mathrm{Aa}$ & GMA & 90.2 & No EB Weld & 0.25 & Center/run-off & Transverse & 49.1 & 0.60 \\
\hline $20 / A b$ & GMA & 90.2 & No EB Weld & 0.25 & Center/run-on & Transverse & 53.5 & 0.60 \\
\hline $20 / A c$ & GMA & 90.2 & No EB Weld & 0.25 & Off-Ctr/run-off & Transverse & 45.2 & 0.50 \\
\hline 20/Ad & GMA & 90.2 & No EB Weld & 0.25 & Off-Ctr/run-on & Transverse & 54.5 & 0.57 \\
\hline $25 / \mathrm{Aa}$ & GMA & 44.5 & EB Welded & 0.25 & Center/Start & Longitudinal & 29.8 & 0.29 \\
\hline $25 / A b$ & GMA & 44.5 & EB Welded & 0.25 & Center/Stop & Longitudinal & 38.9 & 0.37 \\
\hline $25 / A C$ & GMA & 44.5 & EB Welded & 0.25 & Off-Ctr/Start & Longitudinal & 30.9 & 0.22 \\
\hline 25/Ad & GMA & 44.5 & EB Welded & 0.25 & Off-Ctr/Stop & Longitudinal & 47.4 & 0.36 \\
\hline 28/Aa & GMA & 87.0 & EB Welded & 0.25 & Center/Start & Longitudinal & 41.9 & 0.45 \\
\hline $28 / A b$ & GMA & 87.0 & EB Welded & 0.25 & Center/Stop & Longitudinal & 41.8 & 0.49 \\
\hline $28 / A C$ & GMA & 87.0 & EB Welded & 0.25 & Off-Ctr/Start & Longitudinal & 47.7 & 0.49 \\
\hline 28/Ad & GMA & 87.0 & EB Welded & 0.25 & Off-Ctr/Stop & Longitudinal & 48.1 & 0.58 \\
\hline $7 / \mathrm{Aa}$ & GMA & 42.4 & No Tab & 0.25 & Center/Start & Longitudinal & 40.3 & 0.28 \\
\hline 7/Ab & GMA & 42.4 & No Tab & 0.25 & Center/Stop & Longitudinal & 29.4 & 0.23 \\
\hline $7 / A C$ & GMA & 42.4 & No Tab & 0.25 & Off-Ctr/Start & Longitudinal & 26.9 & 0.18 \\
\hline 7/Ad & GMA & 42.4 & No Tab & 0.25 & Off-Ctr/Stop & Longitudinal & 26.5 & 0.20 \\
\hline $19 / \mathrm{Aa}$ & GMA & 90.2 & No $T a b$ & 0.25 & Center/Start & Longitudinal & 33.8 & 0.29 \\
\hline $19 / A b$ & GMA & 90.2 & No Tab & 0.25 & Center/Stop & Longitudinal & 38.3 & 0.30 \\
\hline 19/AC & GMA & 90.2 & No Tab & 0.25 & Off-Ctr/Start & Longitudinal & 42.9 & 0.38 \\
\hline $19 / A b$ & GMA & 90.2 & No Tab & 0.25 & Off-Ctr/Stop & Longitudinal & 50.0 & 0.53 \\
\hline $53 / \mathrm{Aa}$ & GMA & 51.5 & EB Welded & 0.45 & Center/run-off & Transverse & 44.7 & 0.43 \\
\hline $53 / \mathrm{Ab}$ & GMA & 51.5 & EB Welded & 0.45 & Center/run-on & Transverse & 45.3 & 0.35 \\
\hline $53 / A C$ & GMA & 51.5 & EB Welded & 0.45 & Off-Ctr/run-off & Transverse & 42.5 & 0.31 \\
\hline $53 / A d$ & GMA & 51.5 & EB Welded & 0.45 & Off-Ctr/run-on & Transverse & 37.5 & 0.31 \\
\hline $55 / \mathrm{Aa}$ & GMA & 85.0 & EB Welded & 0.45 & Center/run-off & Transverse & 55.5 & 0.95 \\
\hline $55 / A b$ & GMA & 85.0 & EB Welded & 0.44 & Center/run-on & Transverse & 53.1 & 0.67 \\
\hline $55 / \mathrm{Ac}$ & GMA & 85.0 & EB Welded & 0.45 & Off-Ctr/run-off & Transverse & 59.5 & 0.87 \\
\hline $55 / \mathrm{Ad}$ & GMA & 85.0 & EB Welded & 0.45 & Off-Ctr/run-on & Transverse & 46.3 & 0.72 \\
\hline $53 / \mathrm{Aa}$ & GTA/Hot & 51.5 & EB Welded & 0.45 & Center/run-off & Transverse & 47.9 & 0.53 \\
\hline $53 / A b$ & GTA/Hot & 51.5 & EB Welded & 0.45 & Center/run-on & Transverse & 31.1 & 0.40 \\
\hline $53 / A C$ & GTA/Hot & 51.5 & EB Welded & 0.45 & Off-Ctr/run-off & Transverse & 81.3 & 0.99 \\
\hline $53 / \mathrm{Ad}$ & GTA/Hot & 51.5 & EB Welded & 0.45 & Off-Ctr/run-on & Transverse & 43.9 & 0.61 \\
\hline $55 / \mathrm{Aa}$ & GTA/Hot & 85.0 & EB Welded & 0.45 & Center/run-off & Transverse & 37.6 & 0.69 \\
\hline 55/Ab & GTA/Hot & 85.0 & EB Welded & 0.45 & Center/run-on & Transverse & 41.9 & 0.81 \\
\hline $55 / \mathrm{Ac}$ & GTA/Hot & 85.0 & EB Welded & 0.45 & Off-Ctr/run-off & Transverse & 62.4 & 1.06 \\
\hline 55/Ad & GTA/Hot & 85.0 & EB Welded & 0.45 & Off-Ctr/run-on & Transverse & 45.5 & 0.97 \\
\hline
\end{tabular}


TABLE V

CRACK ANALYSIS SUMMARY

\begin{tabular}{|c|c|c|c|c|c|c|c|}
\hline Plate\# & $\begin{array}{l}\text { Weld } \\
\text { Type }\end{array}$ & $\begin{array}{l}\text { Helium } \\
\text { Content } \\
\text { (appm) }\end{array}$ & $\begin{array}{c}\text { Tab } \\
\text { Attachment }\end{array}$ & $\begin{array}{l}\text { Plate } \\
\text { Thick. }\end{array}$ & $\begin{array}{l}\text { Weld } \\
\text { Orient }\end{array}$ & $\begin{array}{l}\text { Normalized } \\
\text { Average } \\
\text { \# cracks/ } \\
\text { weld length } \\
\text { (\#/in.) } \\
\end{array}$ & $\begin{array}{l}\text { Normalized* } \\
\text { Average } \\
\text { Total crack } \\
\text { length/ } \\
\text { weld length } \\
\text { (in.in.) } \\
\end{array}$ \\
\hline 26 & GMA & 44.5 & EB Welded & 0.25 & Trans. & 47.2 & 0.31 \\
\hline 27 & GMA & 96.9 & EB Welded & 0.25 & Trans. & 47.6 & 0.47 \\
\hline 8 & GMA & 42.4 & No EB Weld & 0.25 & Trans. & 48.7 & 0.46 \\
\hline 20 & GMA & 90.2 & No EB Weld & 0.25 & Trans. & 50.5 & 0.56 \\
\hline 25 & GMA & 44.5 & EB Welded & 0.25 & Long. & 37.2 & 0.31 \\
\hline 28 & GMA & 87.0 & EB Welded & 0.25 & Long. & 46.4 & 0.52 \\
\hline 7 & GMA & 42.4 & No Tab & 0.25 & Long. & 32.7 & 0.24 \\
\hline 19 & GMA & 90.2 & No Tab & 0.25 & Long. & 41.2 & 0.40 \\
\hline 53 & GMA & 51.5 & EB Welded & 0.45 & Trans. & 37.6 & 0.31 \\
\hline 55 & GMA & 85.0 & EB Welded & 0.45 & Trans. & 56.6 & 0.85 \\
\hline 53 & GTA/Hot & 51.5 & EB Welded & 0.45 & Trans. & 44.7 & 0.55 \\
\hline 55 & GTA/Hot & 85.0 & EB Welded & 0.45 & Trans. & 49.7 & 0.94 \\
\hline
\end{tabular}

* Normalized to either 45 or 90 appm helium content 


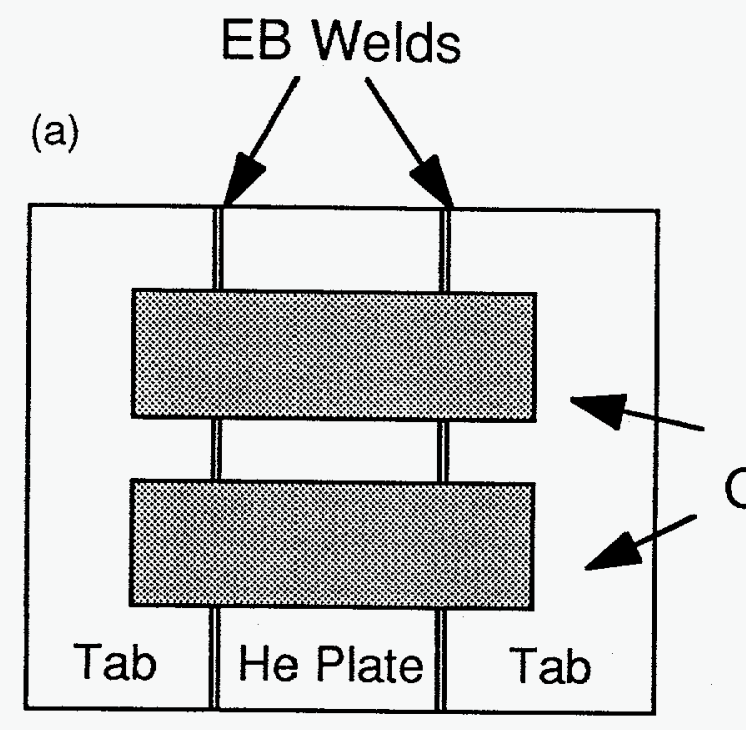

(b)

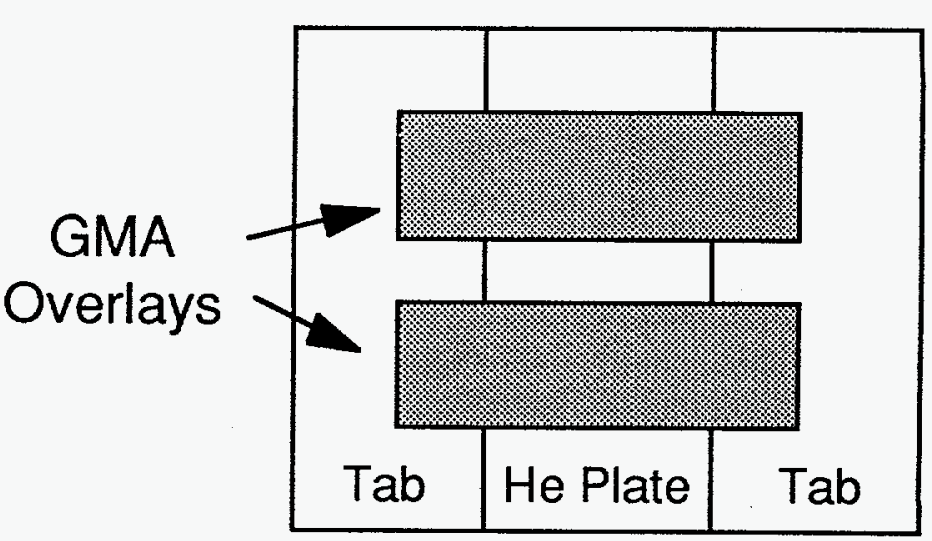

\section{EB Welds}

(c)

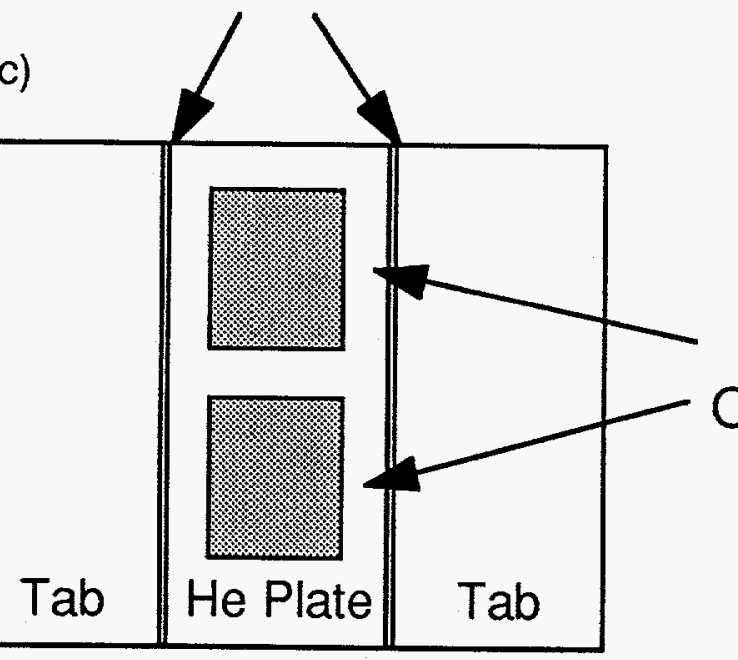

(d)

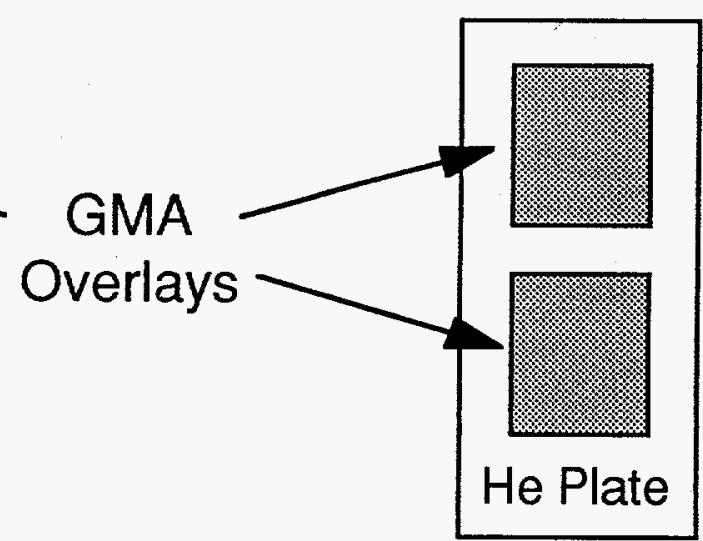

Figure 1. GMA weld orientations (a) transverse with EB welded tabs

(b) transverse without EB weld (c) longitudinal with EB welded tabs

(d) longitudinal with no tabs. 


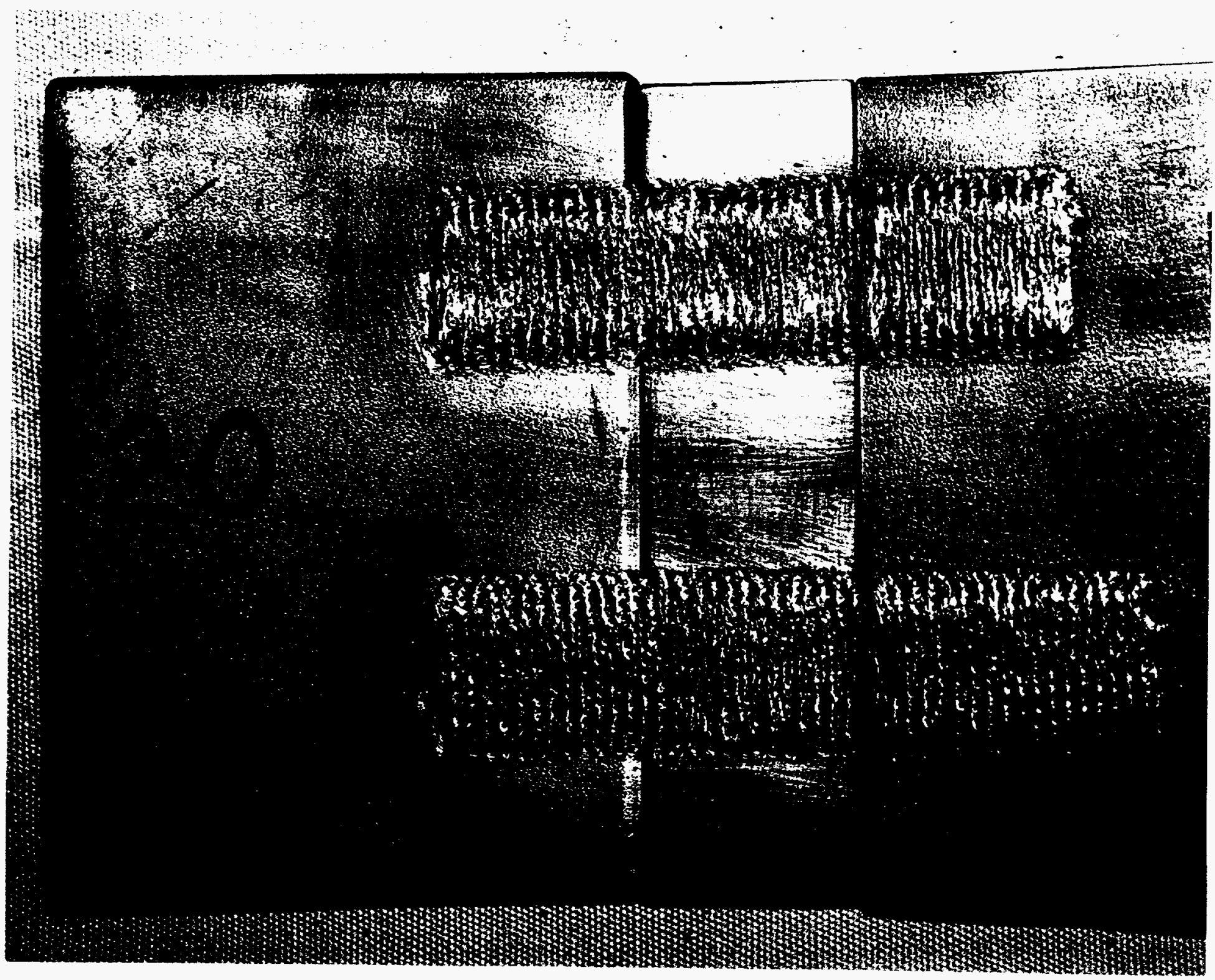

Figure 2. Plate with GMA overlay welds made transversely across center helium charged plate. Uncharged plates not joined to helium charged plate. 


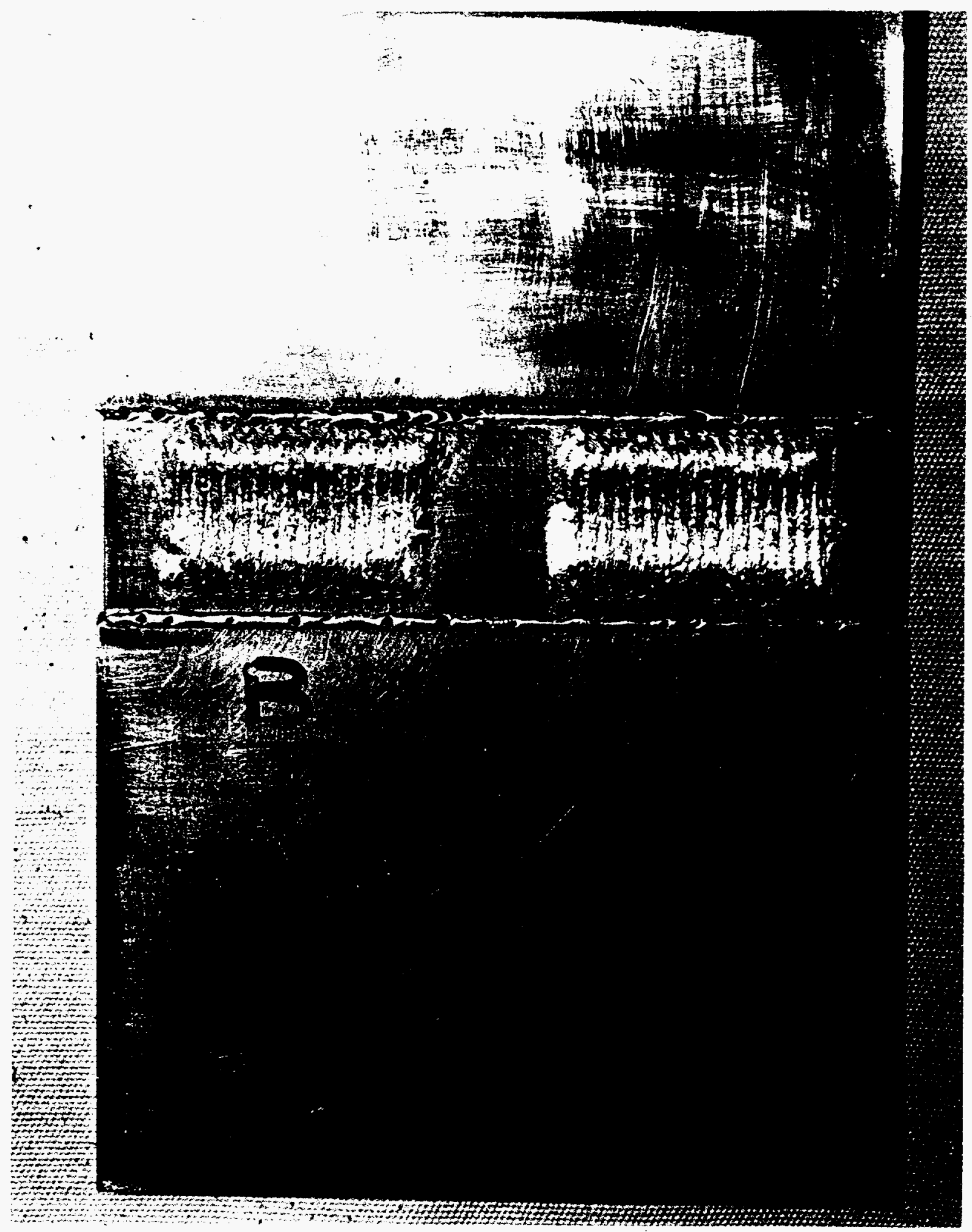

Figure 3. Plates with GMA overlay welds in longitudinal direction on heliumcharged plate. Electron beam welds join uncharged plates to helium charged plates. 


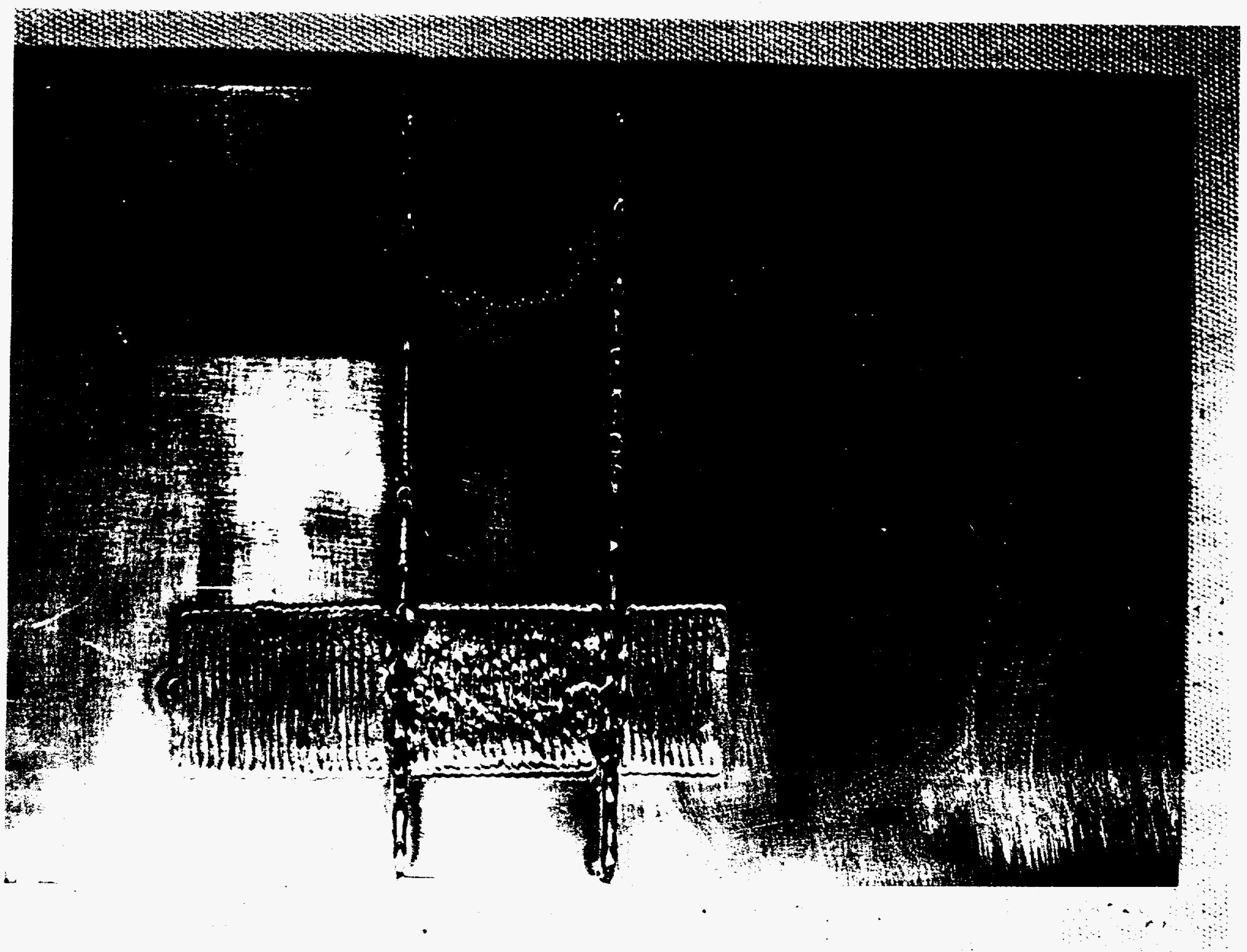




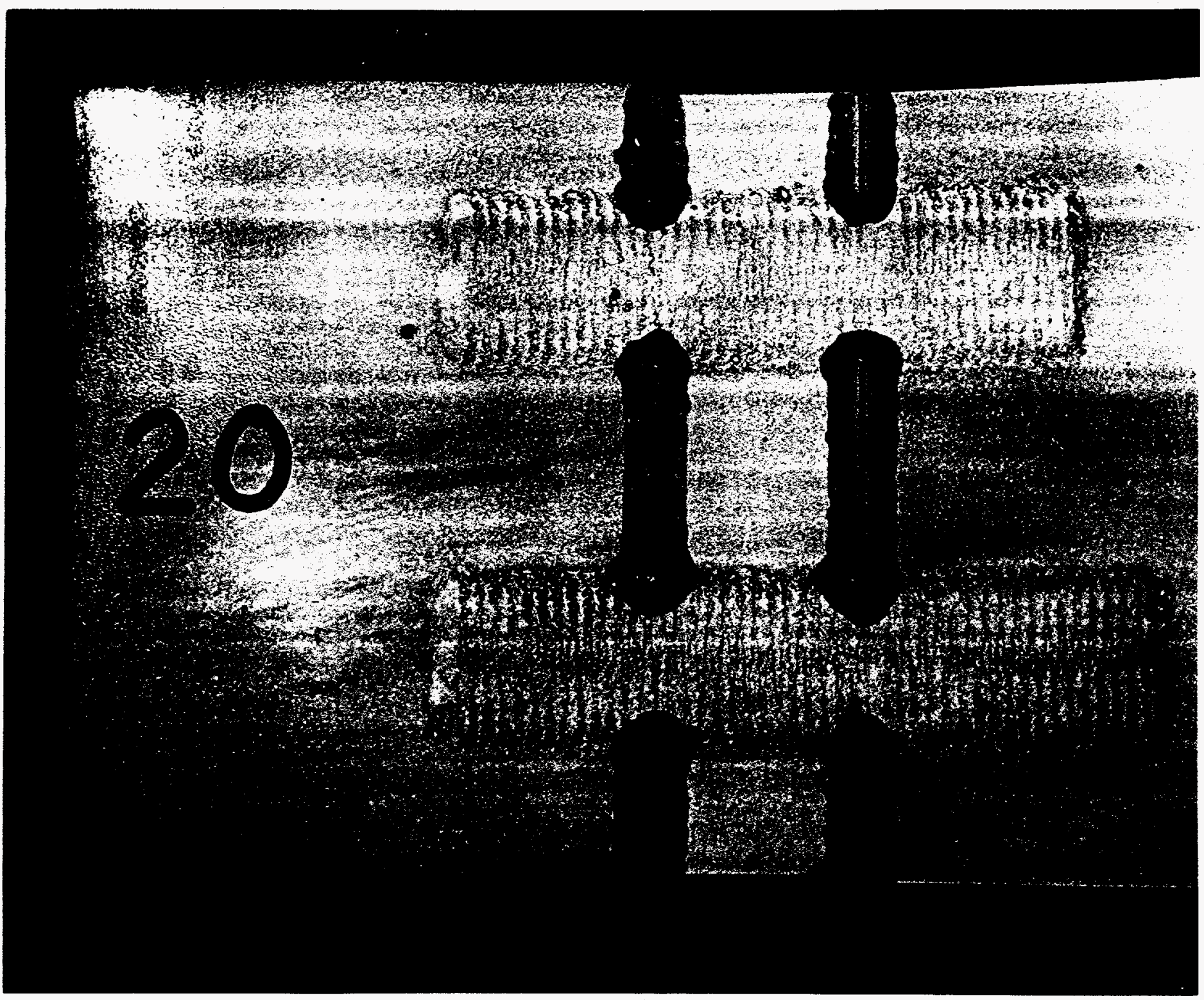

Figure 5. Dye penetrant test of GMA overlay welds shown in Figure 1. Dye associated with the crevice between plates, but no other indications. 


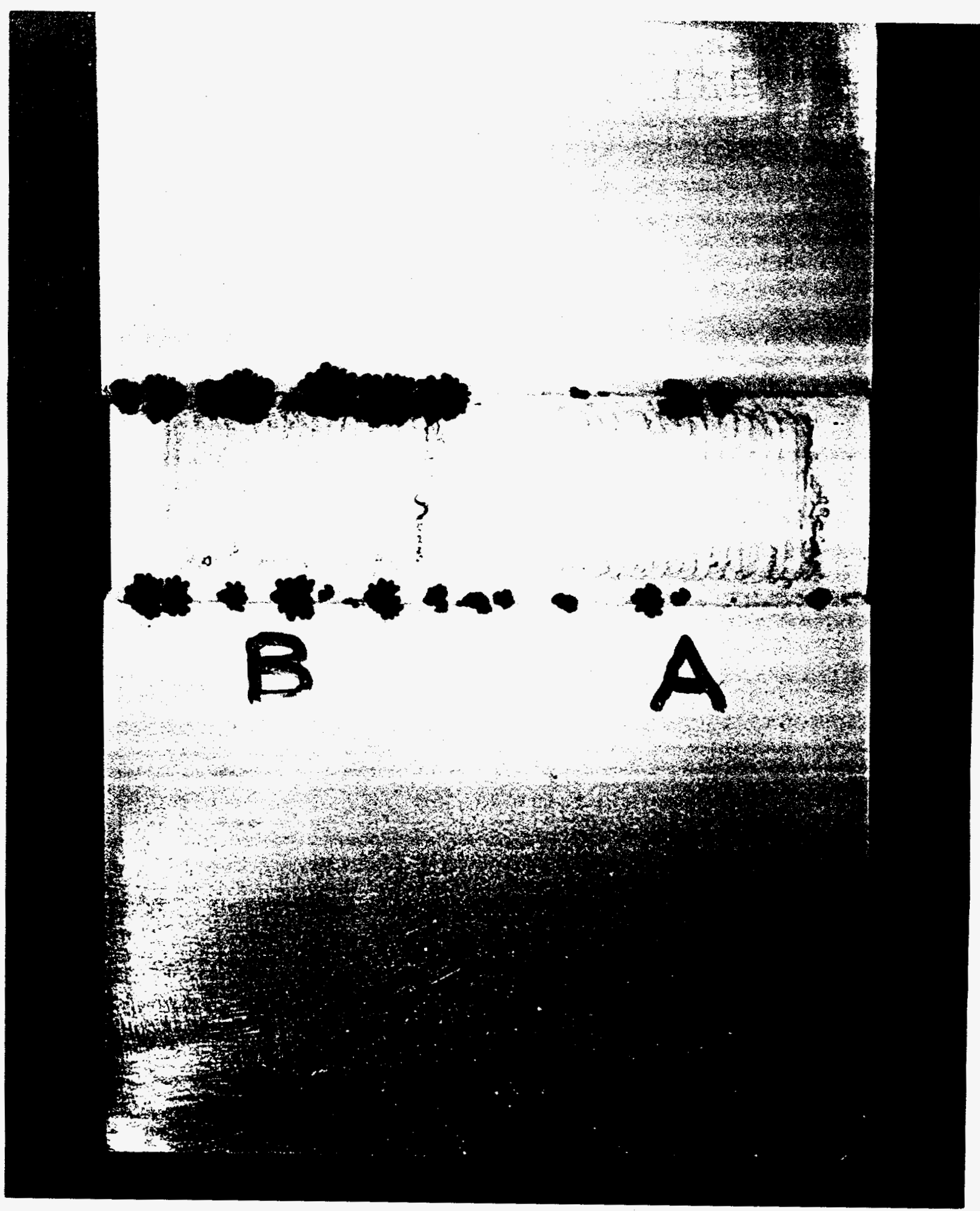

Figure 6. Dye penetrant test of GMA overlay welds shown in Figure 2. Note dye associated with porosity in electron beam welds but no indications elsewhere. 


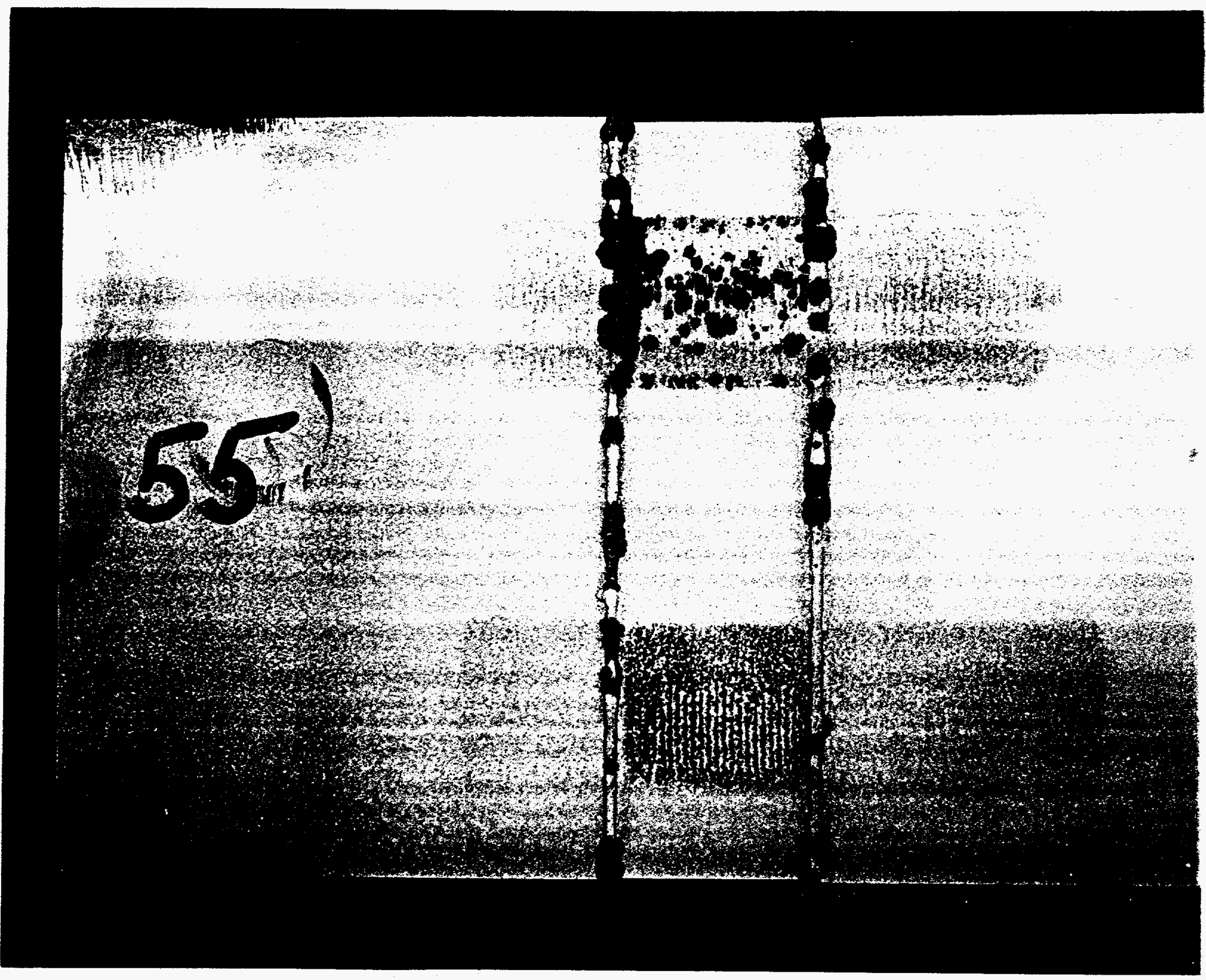

Figure 7. Dye penetrant test of GTA weave beads shown in Figure 3. Note heavy dye indications from porosity in electron beam welds, from porosity in top weave bead over helium-charged plate (but not over uncharged plates), and within bottom bead over helium-charged plate (but not over uncharged plates). 


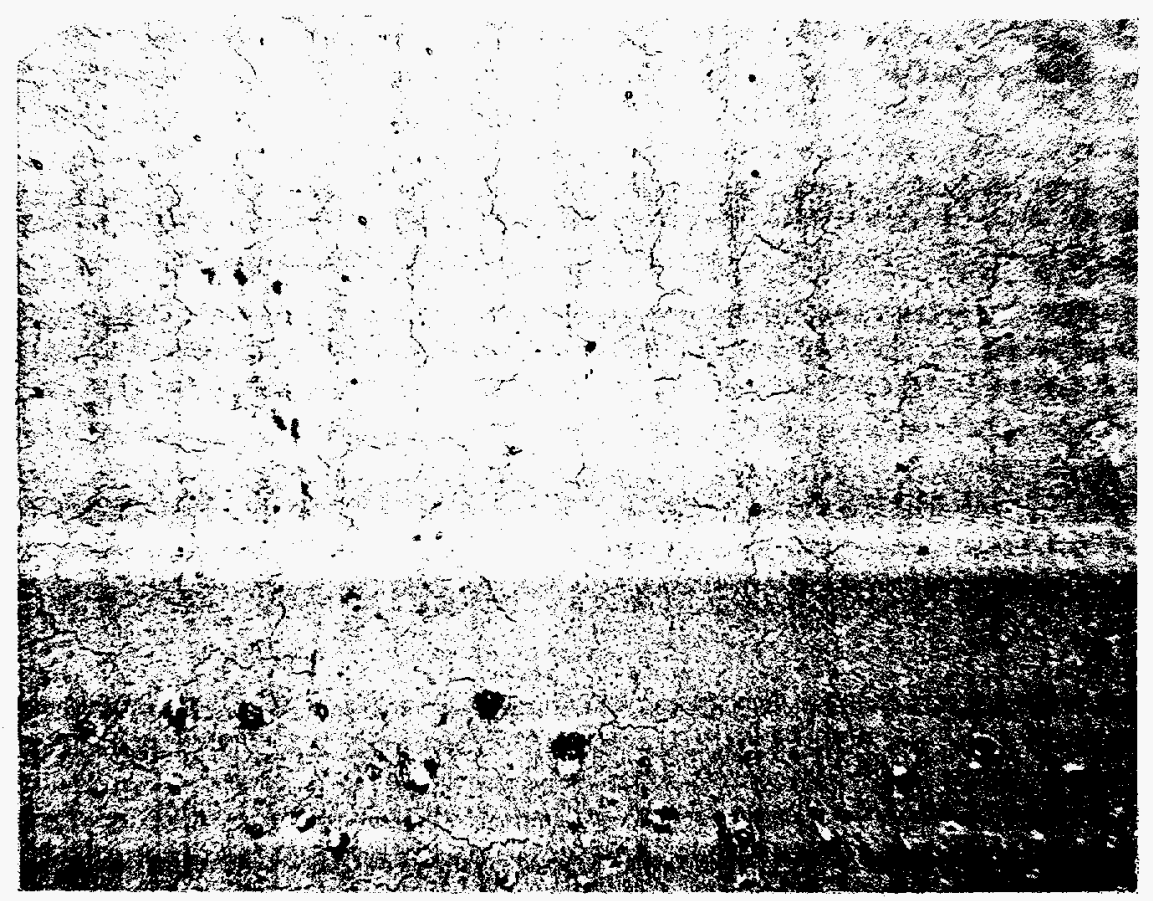

A. Low magnification showing heat bands from arc passes and row of melted spots. $6 \mathrm{x}$.

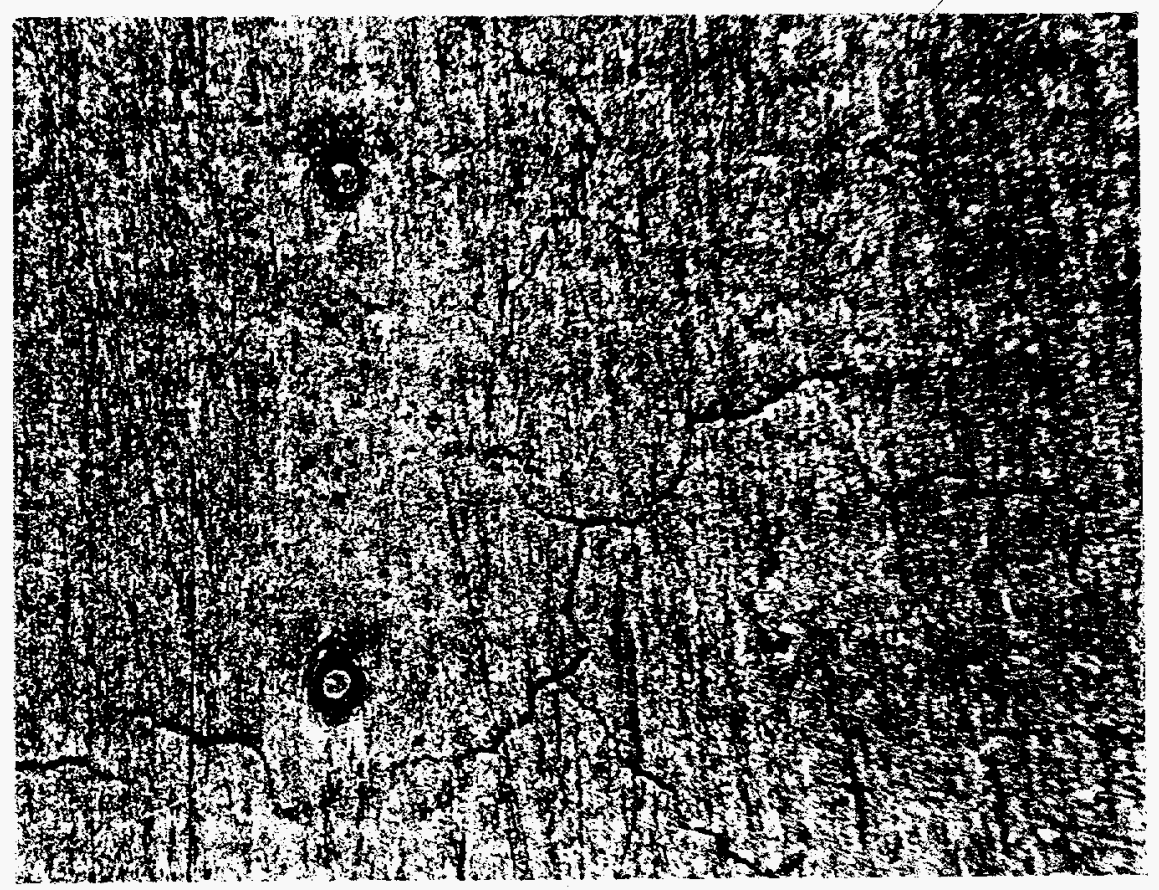

B. Higher magnification showing crack network. 40x.

Figure 8. Surface of low heat GTA weave bead. 
Weld Stop*

Section cuts for Metallographic Examination

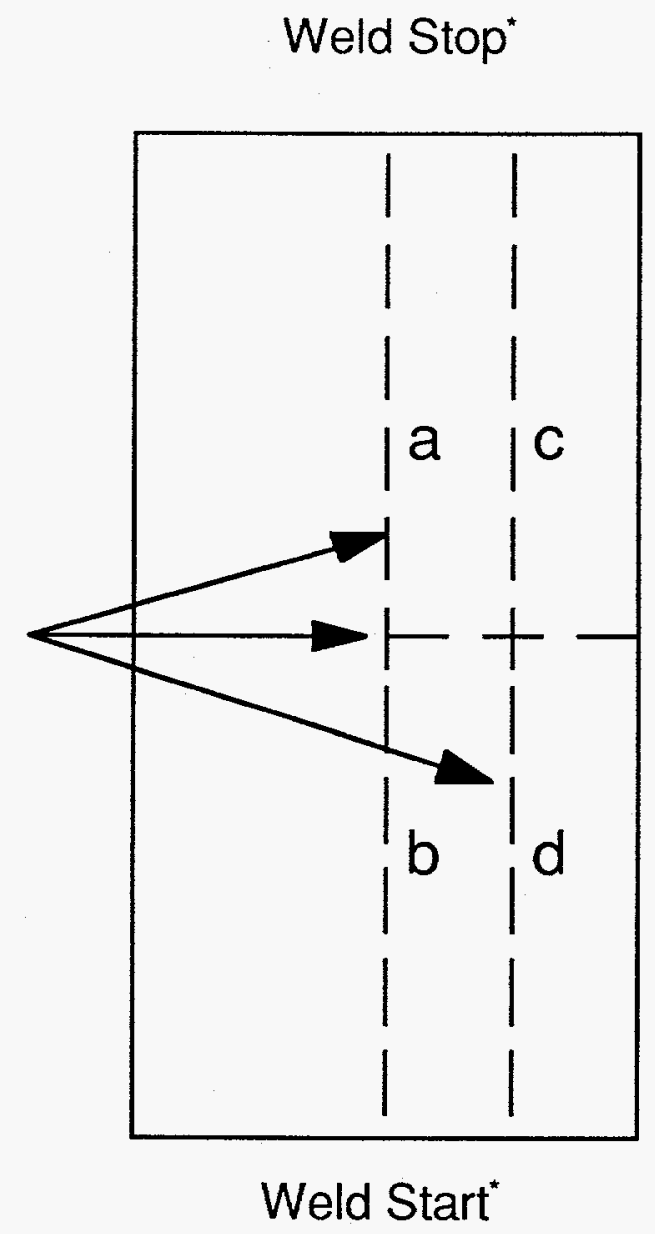

* Weld start and stop locations were opposite on longitudinal sections

Figure 9. Section cuts made in weld for metallographic examination 


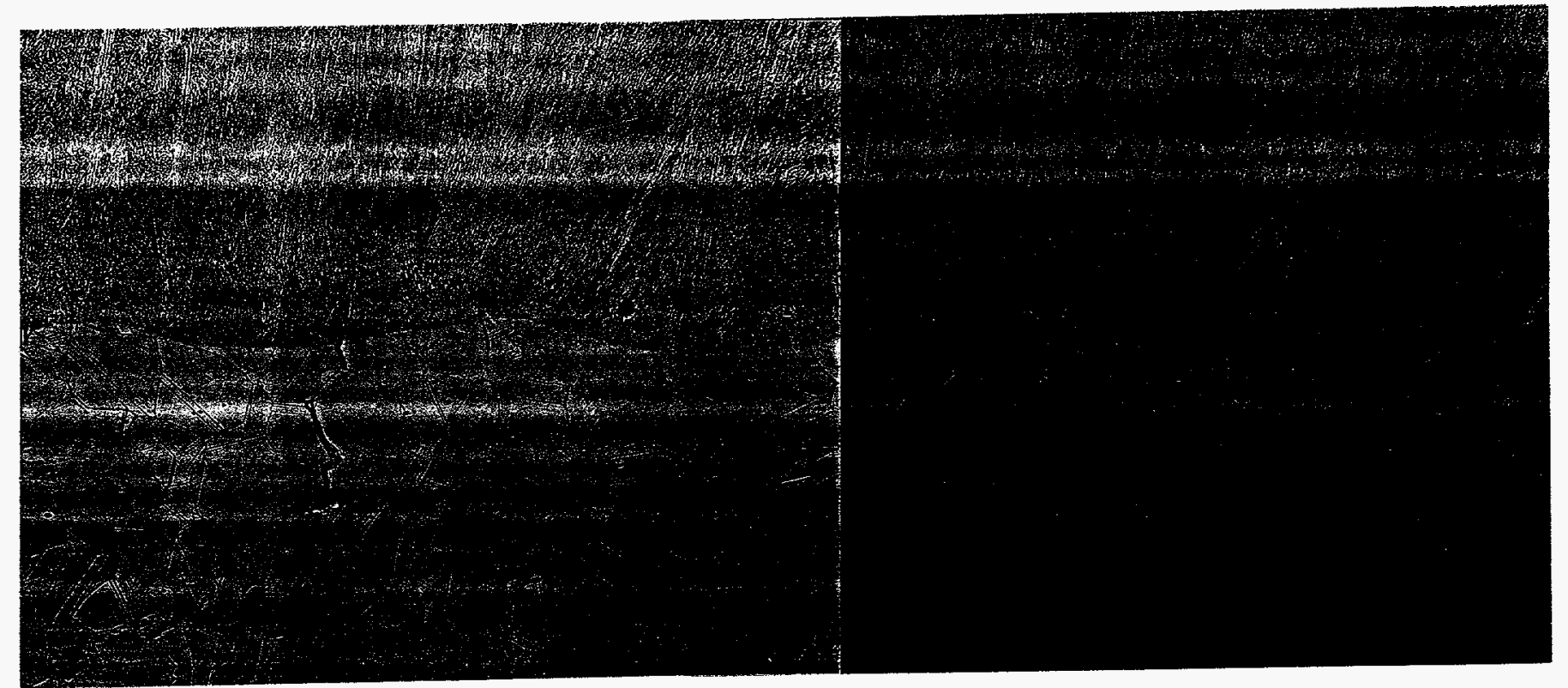

Figure 10. Intergranular underbead cracking from GMA overlay weld on stainless steel plate ( 0.25 inch thick) with high restraint (EB welded tabs) and approximately 45 appm helium content. 50x. 
(a)

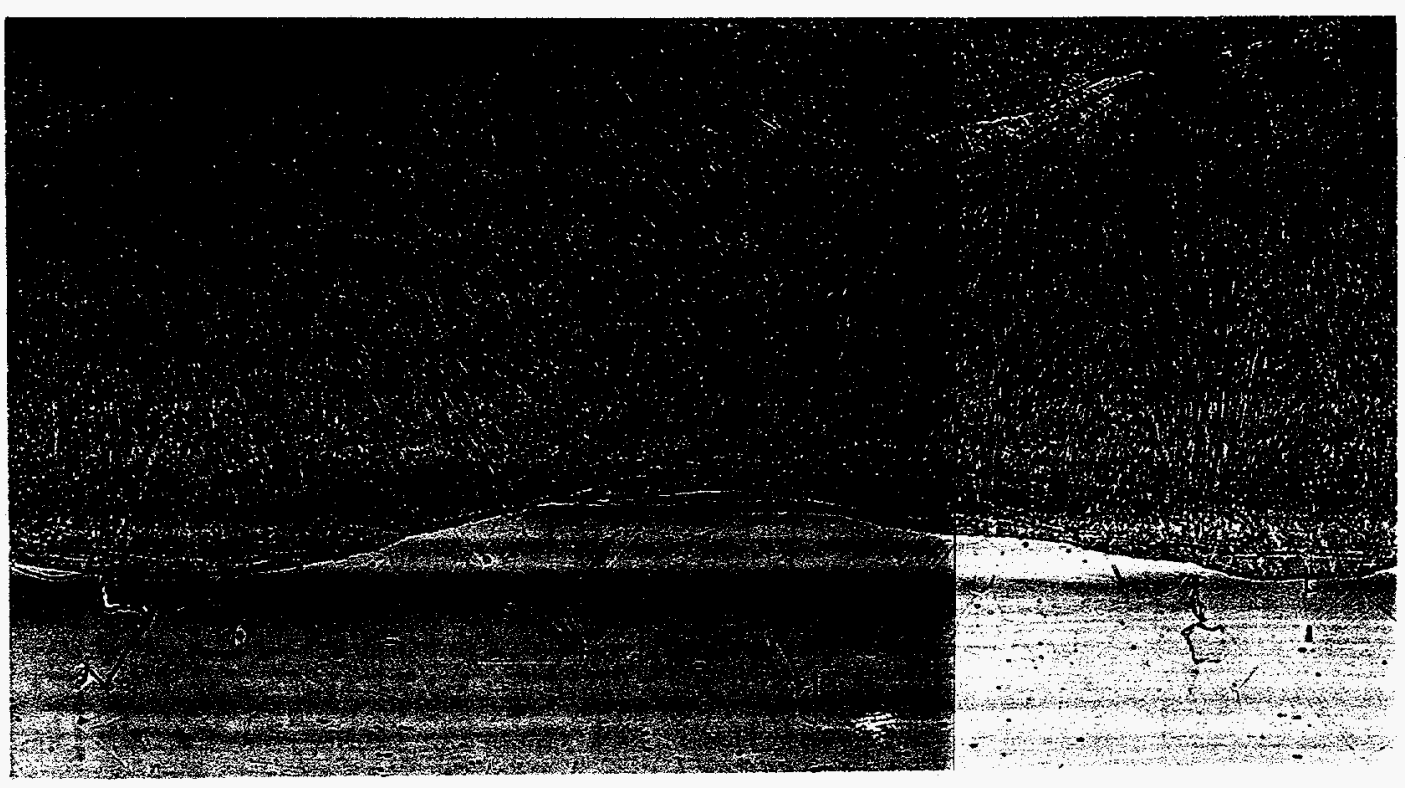

(b)

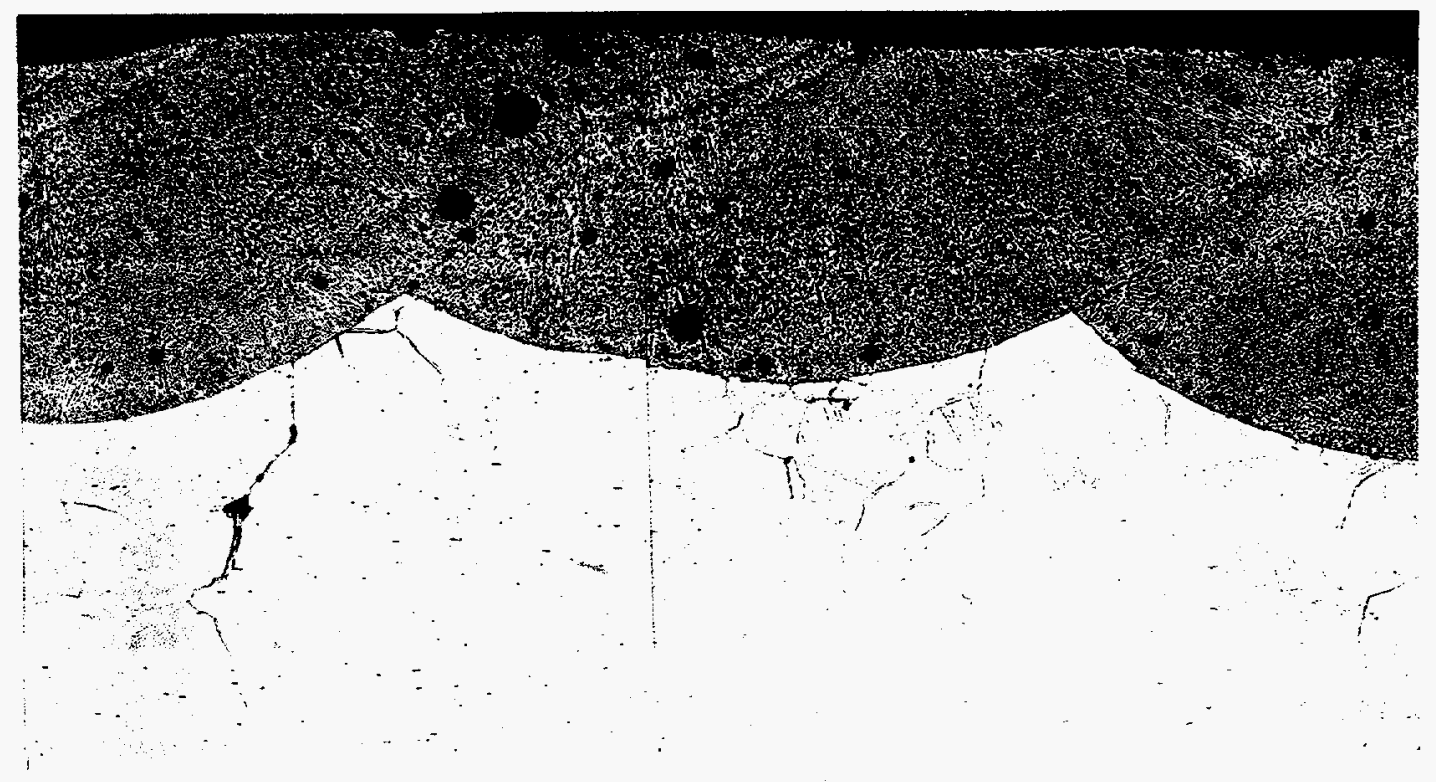

Figure 11. Underbead cracking from (a) GMA overlay weld (b) GTA weave bead with high heat parameters. (Both welds made on same plate: 0.45 inch thick, approximately 90 appm helium content). 50x. 


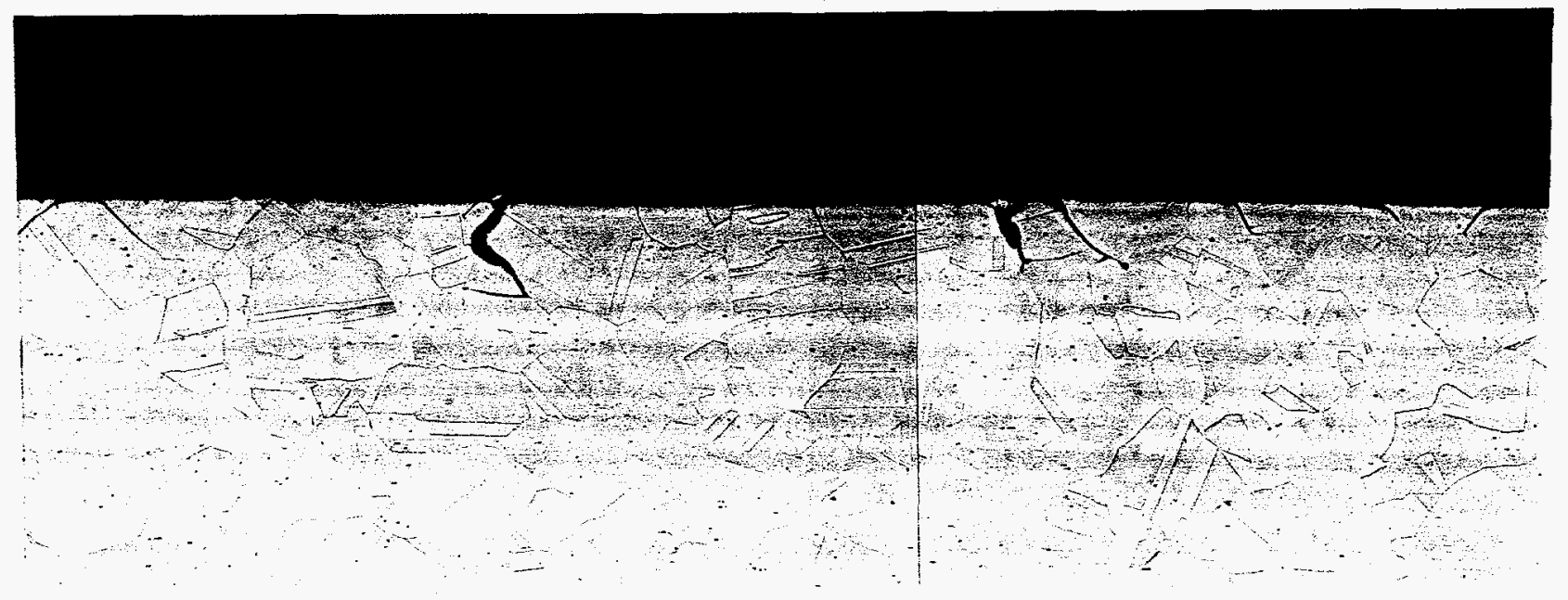

Figure 12. Underbead cracking from GTA weave bead with low heat parameters on 0.45 inch thick plate with approximately 90 appm helium content. 50x. 


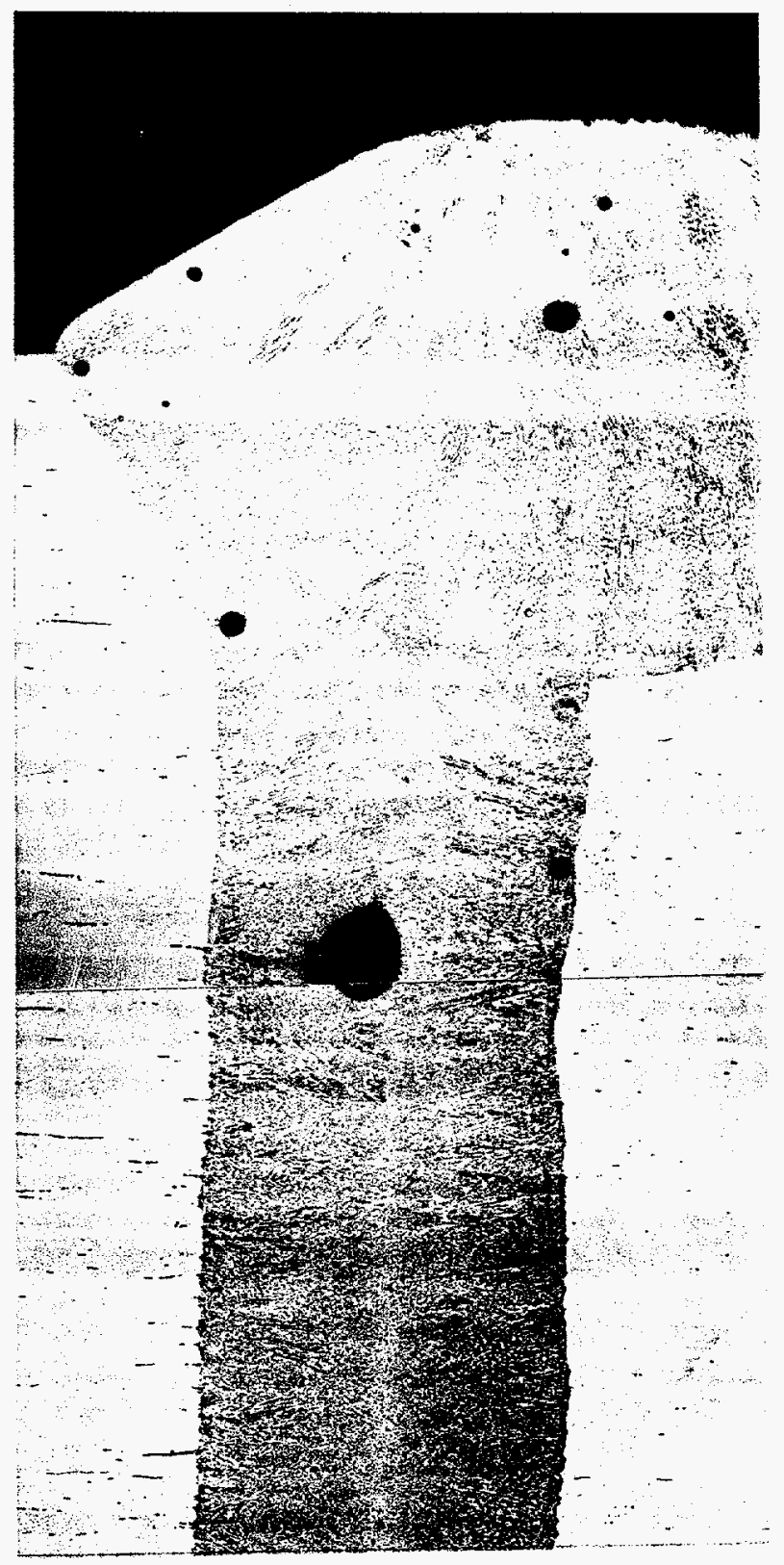

Figure 13. Metallographic section of EB weld between helium containing plate and extender tab plate. $50 x$. 


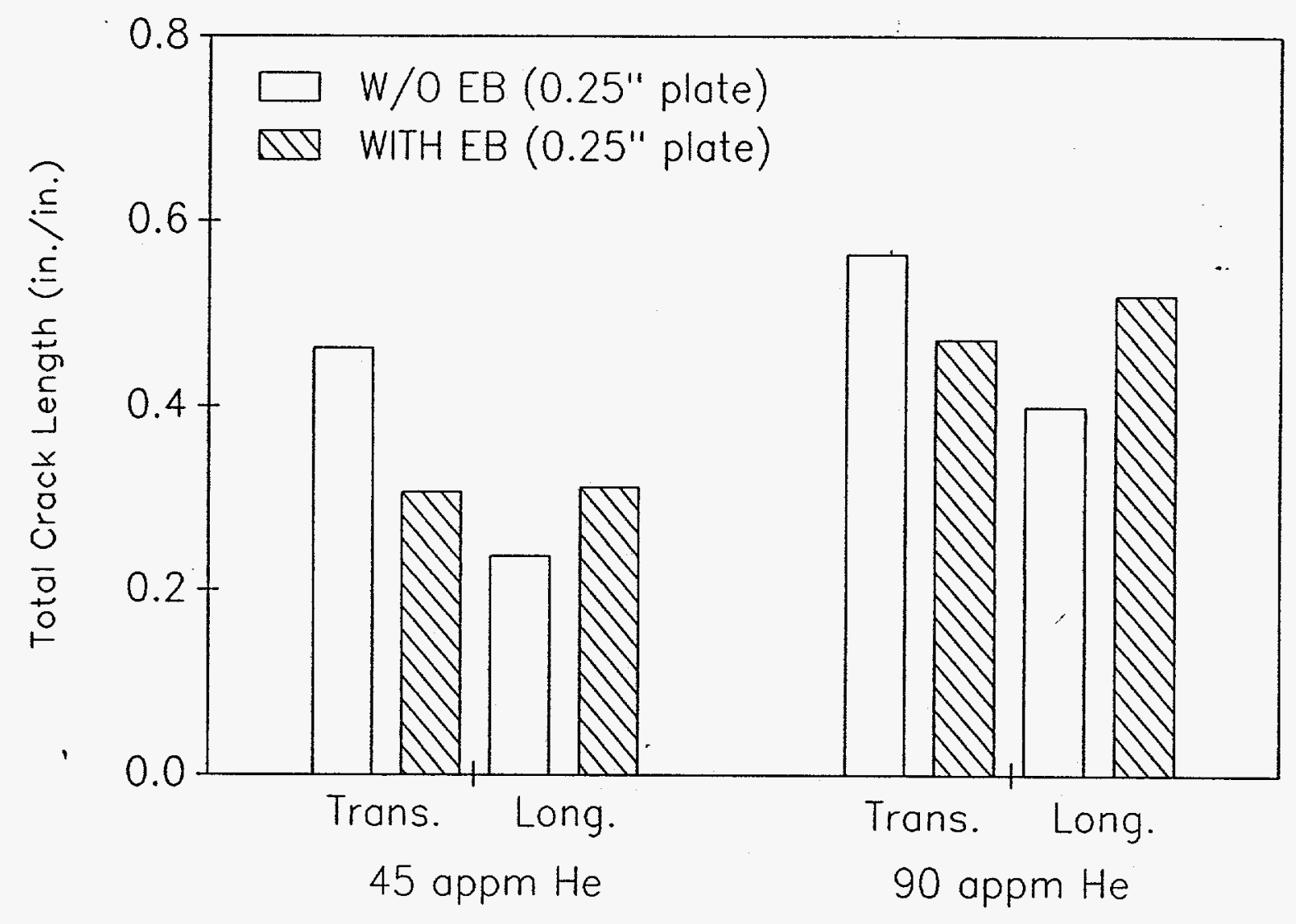

Figure 14. Effect of plate width on underbead cracking (plates with EB weld are three times wider than those without EB weld) 


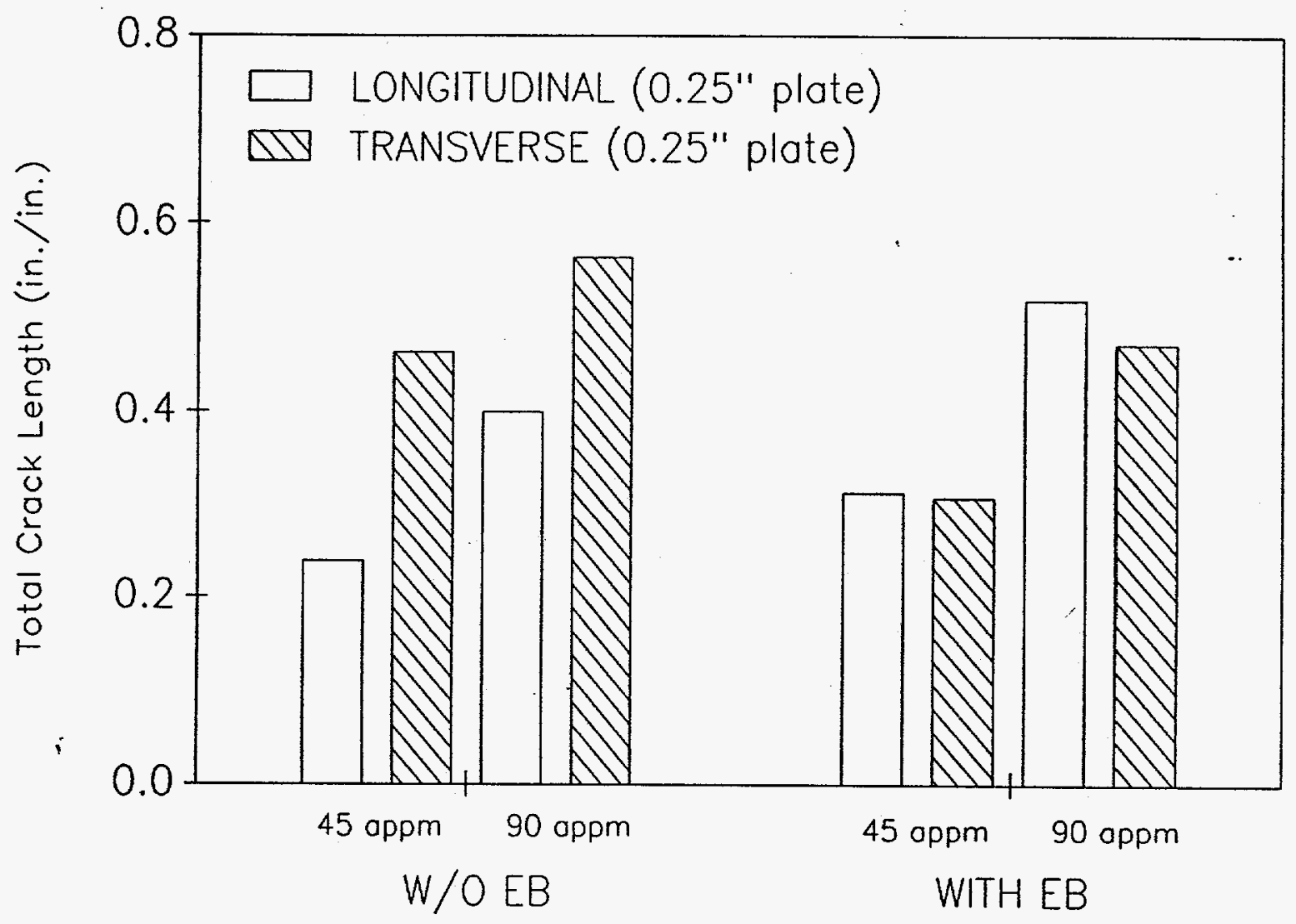

Figure 15. Effect of weld orientation on underbead cracking 


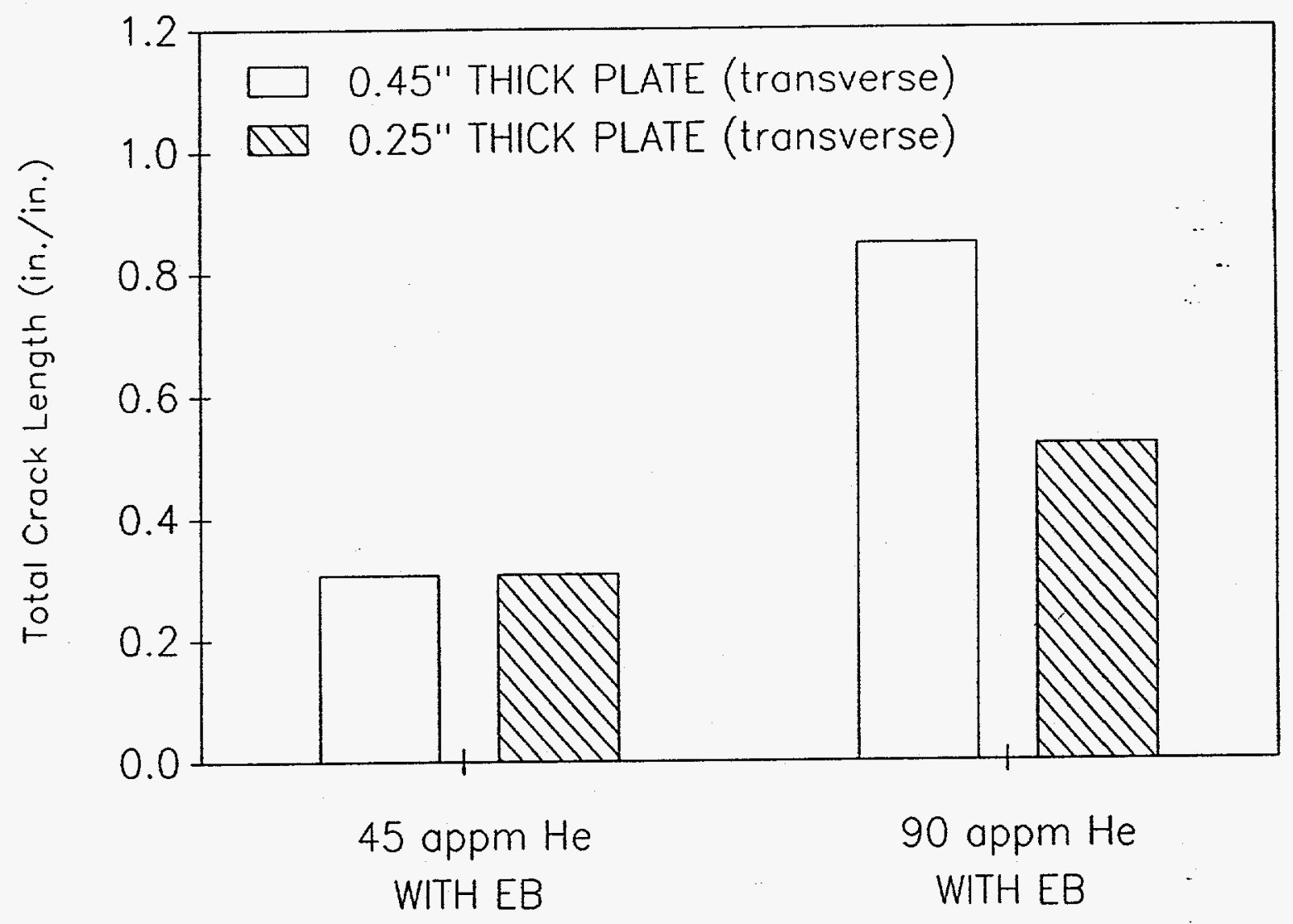

Figure 16. Effect of plate thickness on underbead cracking 


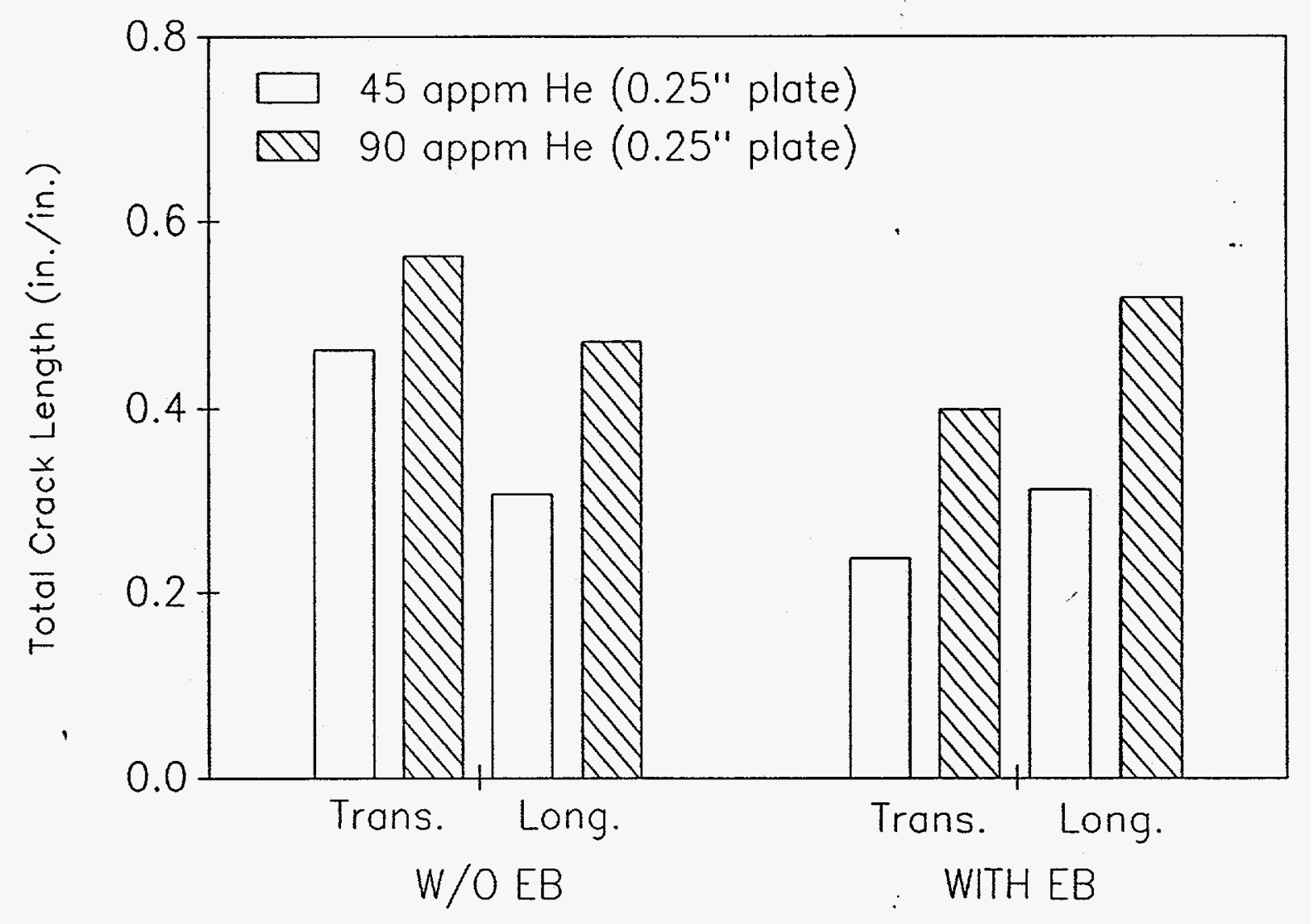

Figure 17. Effect of helium content on underbead cracking 


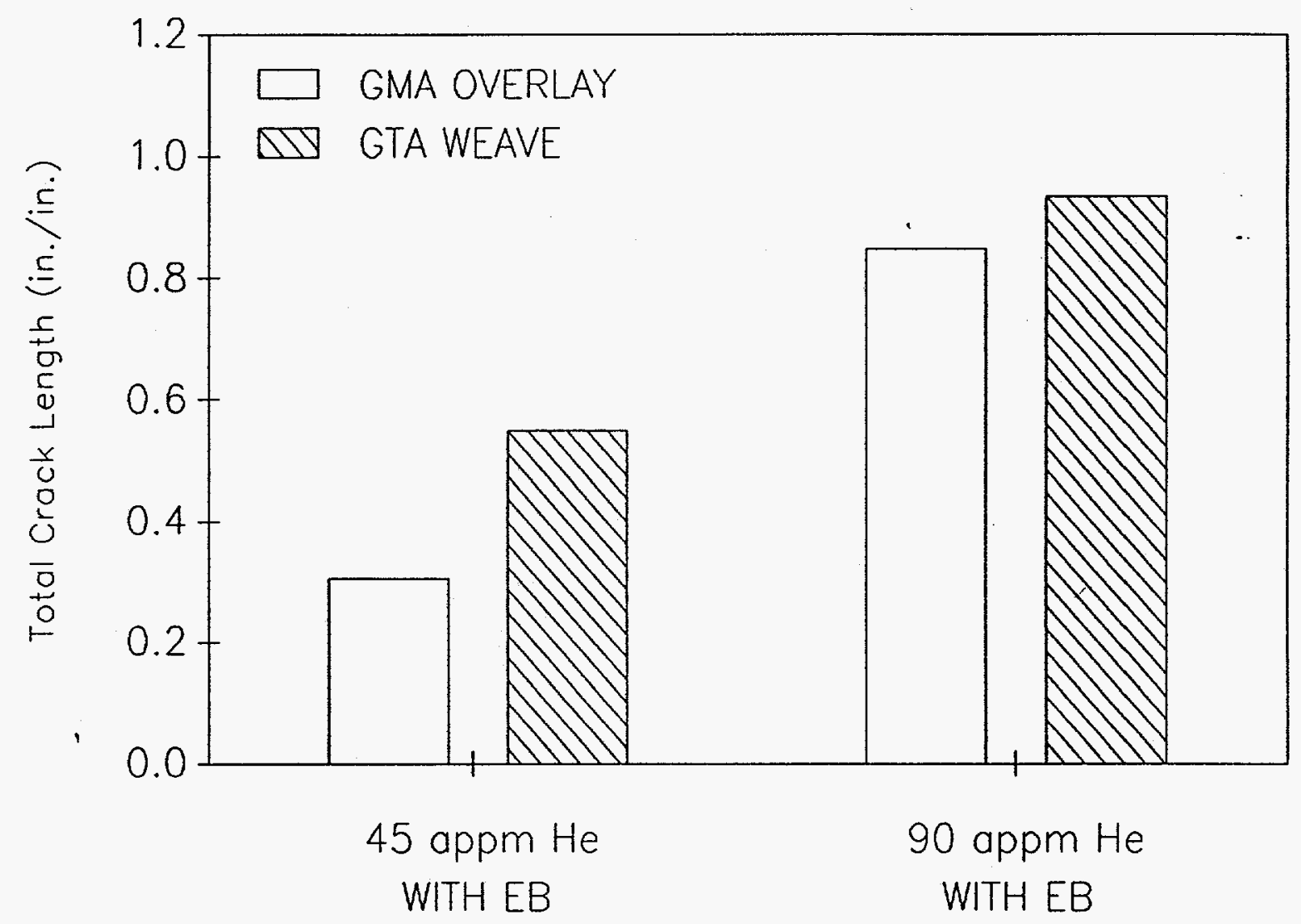

Figure 18. Effect of weld type on underbead cracking 